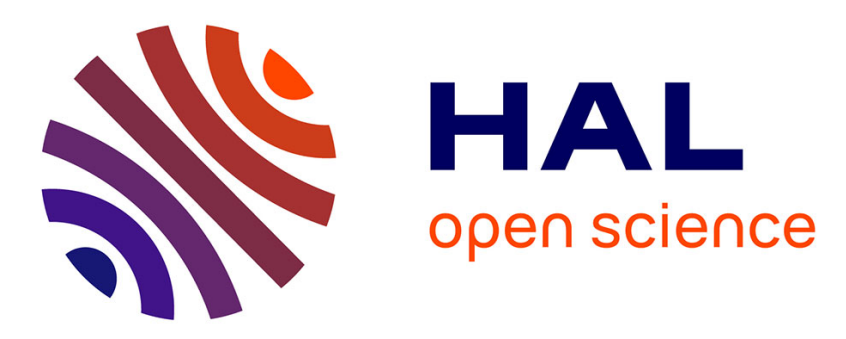

\title{
Twenty million years of continuous deformation along theKarakorum fault, western Tibet: A thermochronological analysis.
}

Franck Valli, Nicolas Arnaud, Philippe-Hervé Leloup, Edward Sobel, Gweltaz Mahéo, R. Lacassin, Stéphane Guillot, Haibing Li, Paul Tapponnier, Xu Zhiquin

\section{To cite this version:}

Franck Valli, Nicolas Arnaud, Philippe-Hervé Leloup, Edward Sobel, Gweltaz Mahéo, et al.. Twenty million years of continuous deformation along theKarakorum fault, western Tibet: A thermochronological analysis.. Tectonics, 2007, 26, pp.TC4004. 10.1029/2005TC001913 . hal-00197561

\section{HAL Id: hal-00197561 https://hal.science/hal-00197561}

Submitted on 17 Dec 2007

HAL is a multi-disciplinary open access archive for the deposit and dissemination of scientific research documents, whether they are published or not. The documents may come from teaching and research institutions in France or abroad, or from public or private research centers.
L'archive ouverte pluridisciplinaire HAL, est destinée au dépôt et à la diffusion de documents scientifiques de niveau recherche, publiés ou non, émanant des établissements d'enseignement et de recherche français ou étrangers, des laboratoires publics ou privés. 


\section{0 million years of continuous deformation along the Karakorum fault, Western Tibet: a thermochronological analysis}

Franck Valli (1), Nicolas Arnaud (2), Philippe Hervé Leloup (3), Edward R. Sobel (4) Gweltaz Mahéo, (3) Robin Lacassin (1) Stéphane Guillot (5), Haibing Li (6-1) Paul

Tapponnier (1), Zhiqin $\mathrm{Xu}(6)$

(1) UMR7578-CNRS Institut de Physique du Globe de Paris, 75252, Paris, France, (2) Géosciences Montpellier, Université de Montpellier 2, CNRS UMR5243, 34095, Montpellier, France, (3) UMR5570-CNRS Univ. Claude Bernard, 69622, Villeurbanne, France, (4) Univ. Potsdam, Institut für Geowissenschaften 14476, Potsdam, Germany, (5) LGCA, Univ. J. Fourier, 38400, St-Martin d'Hères, France, (6) Institute of Geology CAGS, 100037, Beijing, China,

Nicolas.Arnaud@gm.univ-montp2.fr Fax:

The role of the Karakorum fault zone (KFZ) is debated. South of $33^{\circ} \mathrm{N}$, ongoing dextraloblique slip along the SW edge of the Gar basin exhumes metamorphic and magmatic rocks of the Ayilari range. Minerals have recorded a continuum of deformation from temperatures $>600-400^{\circ} \mathrm{C}$ down to $<250{ }^{\circ} \mathrm{C}$. The ${ }^{40} \mathrm{Ar} /{ }^{39} \mathrm{Ar}$ ages, the oldest being $21.2 \pm 1.0 \mathrm{Ma}$, yield minimum estimates for the initiation of the KFZ. These are in agreement with the $\mathrm{U}-\mathrm{Th} / \mathrm{Pb}$ ages constraining the onset of deformation at $>=25-22 \mathrm{Ma}$. Thermochronologic results show slow cooling for the period $\sim 21-14 \mathrm{Ma}$, followed by rapid cooling between $\sim 14-4 \mathrm{Ma}$. These data demonstrate that right-lateral motion was in progress in the early-Miocene and that shear continued at least until $4 \mathrm{Ma}$, pointing to $>=20 \mathrm{My}$ of deformation along the fault. Greenschist facies deformation superimposed upon the medium to high-grade deformation mark a kinematic change from pure dextral to dextral-normal motion associated with the onset of rapid cooling. At the regional scale, the coexistence of transtension in the Gar basin with transpression documented along the Pangong range further north suggests another example of the "zipper tectonics" model developed along the Red River fault. The kinematic 
shift induced the rise of the Ayilari range starting at 16-12 Ma and the incision of major river courses. The Indus River might have become captive of the relief at this time. The river's120 $\mathrm{km}$ of apparent offset implies dextral motion at a long-term rate of $>=8.5 \pm 1.5 \mathrm{~mm} / \mathrm{yr}$.

Keywords: Tibet, Karakorum, strike-slip, slip-rate, ${ }^{40} \mathrm{Ar} /{ }^{39} \mathrm{Ar}$, Thermochronology

\section{Introduction}

The understanding of how strain is partitioned between shortening and lateral extrusion during continent-continent collision hinges on the determination of the geometry, kinematics, slip rate, and life span of major crustal-scale faults. In the Indo-Asian collision, it is clear that thrusting in the Himalaya absorbs a significant portion of the northward indentation of India through north-south shortening. It remains debated, however, whether strike-slip shear zones are long-lasting, lithospheric features, steadily accommodating large amounts of strain during long time spans (e.g., [Tapponnier et al., 2001]), or short-lived transient features, restricted to the crust, that contribute to distributed regional deformation (e.g., [Molnar and Houseman, 2004]).

In southern and western Tibet, north of the Himalayas, the $1000 \mathrm{~km}$ long dextral Karakorum Fault zone (KFZ) may be a key to assess this issue (Figure 1). Published estimates of the age of initiation of the KFZ vary greatly between $\geq 11$ Ma [Matte et al., 1996], <5 Ma (Searle, 1996), <18 Ma [Searle et al., 1998, and references therein], <13 Ma

[Murphy et al., 2000; 2002], $\geq 23 \mathrm{Ma}$ [Lacassin et al., 2004], and between $13.7 \pm 0.3$ and $15.7 \pm 0.5 \mathrm{Ma}[$ Phillips et al., 2004], Long term slip-rate estimates averaged on the Pleistocene to present time period also vary over more than one order of magnitude, from 
$\sim 30 \mathrm{~mm} / \mathrm{yr}$ [Avouac and Tapponnier, 1993; Liu, 1993; Matte et al., 1996], $10.7 \pm 0.7 \mathrm{~mm} / \mathrm{yr}$ [Chevalier et al., 2005], to $\sim 4 \mathrm{~mm} / \mathrm{yr}$ [Brown et al., 2002; Murphy et al., 2002]. A slip-rate of $10 \pm 3 \mathrm{~mm} / \mathrm{yr}$ was averaged for the entire life span of the fault [Lacassin et al., 2004].

The present article focuses on the Ayilari range west of the Gar-Baer pull-apart basin, where metamorphic rocks deformed by the KFZ are locally exhumed. ${ }^{40} \mathrm{Ar} /{ }^{39} \mathrm{Ar}$ dating on syn-tectonic minerals yield estimates for the minimum initiation age of the KFZ and provide indications of continuous fault activity. Together with fission track and U-Th-He ages on apatite, they provide the time-temperature evolution of metamorphic rocks and allow estimates of the minimum long-term slip-rate of the KFZ.

\section{Geological frame framwork?}

The KFZ is one of the most impressive morphological feature of Asia, visible on all regional satellite images and Digital Elevation Models (DEM). The active Karakorum fault is mainly strike-slip and exhibits a $142^{\circ} \mathrm{N}$ trending, $\sim 700 \mathrm{~km}$ long, linear trace, linking the Mustag Ata region in the Chinese Pamir $\left(\sim 38^{\circ} 20^{\prime} \mathrm{N}, 75^{\circ} 10^{\prime} \mathrm{E}\right)$ to the Shiquanhe area $\left(\sim 32^{\circ} 30^{`} \mathrm{~N}, 80^{\circ} 00^{`} \mathrm{E}\right.$; Figure 1).

South of Shiquanhe, the KFZ widens into a long $(150 \times 15 \mathrm{~km})$ double rhomb-shaped basin limited by NNW-SSE striking active faults (Figure 2 and 3) with geomorphic characteristics indicating a normal component of slip ( [Armijo et al., 1989; Lacassin et al., 2004; Matte et al., 1996]). Southeastward, the active trace of the Karakorum fault (KF) continues for at least $150 \mathrm{~km}$ and becomes parallel to the Indus suture $\left(105^{\circ} \mathrm{N}\right.$, [Lacassin et al., 2004; Ratschbacher et al., 1994]). 
Along the southwestern edge of the northern rhomb-shaped basin (the Gar basin), cumulative scarps tens of meters high cutting late Pleistocene moraines, $2 \mathrm{~km}$ high triangular facets, and perched glacial valleys attest to a recent vertical throw on the fault (Figure 3 and 4, [Matte et al., 1996]). These characters led Armijo et al. [1989] to interpret the Gar basin to be an active, dextral pull-apart basin. Uplift due to movement along the active normal faults brings to the surface deformed metamorphic and magmatic rocks that form the North Ayilari range. The samples studied in this paper come from this range.

Northwest of the Zhaxigang village ( $\mathrm{Z}$ on Fig. 2), and adjacent to the North Ayilari metamorphic and magmatic rocks, a sliver of ophiolitic rocks (gabbro, pyroxenite and basalt) outcrops between two strands of the active fault and most likely represents a piece of the Shyok suture dextrally offset by the Karakorum fault (Figures 1 and 2, [Lacassin et al., 2004]).

Around Shiquanhe (S on Fig. 2), Lower Cretaceous, shallow marine and terrestrial deposits, intruded by granitoids belonging to the Gangdese batholith [Schwab et al., 2004], uncomformably overlie kilometre wide massifs of ophiolitic mélange and locally Permian metasediments [Kapp et al., 2003; Matte et al., 1996]. These are remnants of a late Mesozoic suture [Cheng and Xu, 1987; Kapp et al., 2003; Matte et al., 1996; Ratschbacher et al., 1994]. The Lower Cretaceous formation is in turn uncomformably overlain by Tertiary red conglomerates [Matte et al., 1996]. These series are cut by the Shiquanhe fault, which branches off the well-defined trace of the KF (Figure 2, [Ratschbacher et al., 1994]). This fault bounds the Tertiary Shiquanhe basin to the north and thrusts the Permian-Tertiary sequence above vertical Pliocene-Quaternary sedimentary beds [Matte et al., 1996]. Sedimentation in the Tertiary Shiquanhe basin was interpreted to be contemporaneous with displacement along the fault, suggesting an Oligocene onset of thrusting[Kapp et al., 2003]. 
Crosscutting relationships and thermochronologic data show that the Shiquanhe fault is younger than the other thrusts parallel to it that are mapped northward up to the Risum anticlinorium (Jaggang, Zaduo and Narangjiapo thrusts of Kapp et al. [2003], also see references therein). The thermal history calculated for a granite in the hanging wall of the Shiquanhe fault suggests a maximum shortening of $10 \mathrm{~km}$ across the fault since at least the Oligocene [Kapp et al., 2003], whereas a minimum shortening of $3 \mathrm{~km}$ is estimated for the same period of time from the depth of the Tertiary Shiquanhe basin. The Shiquanhe fault may also have accommodated a recent dextral component of deformation and be connected to the N-S trending rifts of western Tibet [Armijo et al., 1989; Ratschbacher et al., 1994].

South of the Ayilari range, the Sutlej basin is composed of conglomerates, sandstones, and siltstones cut by the impressive, up to $1000 \mathrm{~m}$ deep, canyons of the Sutlej river and its tributaries [Gansser, 1964]. The basement is composed of folded Meso-Cenozoic rocks pertaining to the Tethian series [Jiao et al., 1988]. Fold axes have a roughly constant orientation of $\mathrm{N} 125^{\circ} \mathrm{E}$, oblique to the trend of the Ayilari range (Figure 2). Syn-sedimentary deformation features indicate that these folds were active during Mio-Pliocene time [Zhang et al., 2000], and may still be active since rivers form deep and narrow gorges where they cross anticlines. The contact between this basin and the Ayilari range is sharp, parallel to the active KFZ, and presents a strong topographic gradient (slope $>25 \%$ ) with a differential elevation of more than $1000 \mathrm{~m}$. This suggests recent vertical displacement along the southern flank of the Ayilari range. From large-scale mapping, Lacassin et al. [2004] postulated rightlateral strike-slip motion along this flank that would correspond to a southern strand of the KFZ (Figure 1).

This southern fault strand would connect with the northern strand of the KFZ by $\mathrm{N} 110^{\circ} \mathrm{E}$ trending faults, which isolate kilometer to tenths of kilometers wide slivers of Paleo- 
Cenozoic metasediments, black slates, meta graywackes, granitoids; ophiolites and conglomerates formed of peridotites, gabbros and basalts, a tectonic mélange consisting of blocks of serpentine, harzburgite, radiolarite, and Permo-Triasic hallstatt limestone, and Tertiary sandstone and conglomerate with boulders of volcanic rocks, granodiorite, sandstone and radiolarite (Fig. 2). The slivers of ophiolites and of tectonic mélange probably represent the Indus suture zone dismembered by strike slip deformation [Armijo et al., 1989; Lacassin et al., 2004]. The Meso-Cenozoic meta graywackes might be deformed equivalents to the Cretaceous Xigaze group which widely outcrops $400 \mathrm{~km}$ eastward (e.g., Burg, 1983) as a $20 \mathrm{~km}$ wide strip along the northern side of the Indus suture.

\section{Field observations in the North Ayilari range}

The North Ayilari Range consists of high grade metamorphic rocks and of variously deformed granitoids that we studied along 6 sections in valleys perpendicular to the trend of the range (Figures 2 and 4).

\subsection{Structural observations}

Frontal parts of sections 2, 3 and 6 show the development of strong cataclasis, including pseudotachylites, and low-temperature brittle-ductile deformation (Figure 4). The corresponding foliation was acquired in greenschist facies metamorphic conditions characterized by chlorite growth and is parallel to the active fault. The mean foliation trends $\sim \mathrm{N} 129^{\circ} \mathrm{E}$ and $\operatorname{dips} \sim 36^{\circ} \mathrm{E}$ on section $2, \sim \mathrm{N} 123^{\circ} \mathrm{E}-45^{\circ} \mathrm{NE}$ for section 3 , and $\sim \mathrm{N} 168^{\circ} \mathrm{E}-$

$40^{\circ} \mathrm{NE}$ on section 6 (Figure 5). Lineations are underlined by chlorite and indicate a dextral- 
normal sense of shear characterized by either an oblique lineations with a pitch of $35-60^{\circ} \mathrm{SE}$ (section 6), or a partitioning between purely normal and purely strike slip deformation components with two groups of lineations trending $\mathrm{N} 104-140^{\circ} \mathrm{E}$ and $29-67^{\circ} \mathrm{NE}$, respectively (sections 2, 3). This kinematics of low-grade deformation is consistent with the right-lateral motion deducted from the morphology along the adjacent active fault.

This predominant greenschist facies foliation is superimposed upon, and partially overprints, a higher-grade deformation. A few tens of meters inside valleys 2, 3, 6, and straight from the front of valleys 1,4 and 5, chlorite is absent and the rocks were mainly deformed under higher-grade metamorphic conditions. Lineations, made of stretched feldspars and micas, are nearly horizontal and its trend is exceptionally constant from one section to another, and from the frontal parts of sections to $\sim 10 \mathrm{~km}$ inside the range (N139 \pm $6^{\circ} \mathrm{E}$, at $2 \sigma$ confidence level, Figures 5 and $6 \mathrm{a}$ ). Foliation trend also remains roughly constant at $\sim \mathrm{N} 140^{\circ} \mathrm{E}$; the dip angle decreasing progressively from the valley front $\left(60^{\circ} \mathrm{NE}\right.$, Figures 4 and $6 \mathrm{~b}$ ) to less than $10^{\circ} \mathrm{NE}, \sim 3-5 \mathrm{~km}$ inside the Ayilari range (sections 1 and 4 ). The sense of shear, mainly indicated by S-C structures (Figure 6c) and sigmoidal feldspars (Figure 6d), is unambiguously right-lateral where foliation is steep, and top to the south where it is gently dipping (section 1). Such geometry of the foliation and lineation is consistent with a convex Karakorum strike-slip shear zone with the rocks of the top-northeastern edge displaced dextrally and southeastward.

\subsection{Field relationship, samples location, and geochronological framework}


In the following, the prefix "leuco" is used to qualify rocks rich in leucocratic minerals such as quartz-feldspar-muscovite ( $>95 \%$ of the rock volume). The attribute "two-mica" is assigned to rocks showing a content $\geq 5 \%$ in both white and black mica, whereas the term "biotite-rich" applies to rocks having biotite and muscovite contents $>10 \%$ and $<5 \%$, respectively. In places biotite-rich, leucocratic and two-mica bands and lenses alternate, with the two systematically in contact. We call these rocks "migmatites", as their biotite-rich, leucocratic and two-mica bands and lenses might represent mesosome, leucosome, and melanosome, respectively.

Triangular facets in the northeastern part of section 1 (Figures 3a, 4) exhibit dextrally sheared leucogranitoids (sample L91). The intensity of deformation decreases progressively to a non-deformed leucogranitoid $\sim 300 \mathrm{~m}$ from the front. Landslides deposited at high elevation by glacial moraines prevented us from mapping $5 \mathrm{~km}$ of the section, after which penetratively deformed migmatitic gneiss crops out (L89). There, the foliation is sub horizontal, the lineation strikes $\sim \mathrm{N} 153^{\circ} \mathrm{E}$ roughly parallel to the KF, and the sense of shear, indicated by S-C structures and sigmoidal feldspars, is top to the south. The foliation is locally crosscut by leucocratic veins (L86, L90) that are differentiated magmas originating from a large two-mica granitoid body located $\sim 500 \mathrm{~m}$ southwestward (L87). U-Th-Pb dating on zircons of sample L89 suggest crystallization of the migmatitic gneiss at $23.4 \pm 4.0 \mathrm{Ma}$, while monazites revealed post crystallization event(s) interpreted as hydrothermal activity until $\sim 18 \mathrm{Ma}$ (L89, [Valli, 2005; Valli et al., submitted]).

On section 2 (Figure 4), two-mica gneisses, mylonites, and ultramylonites crop out as a band at least $500 \mathrm{~m}$ thick. Inside the valley, migmatitic gneisses crop out. The leucocratic mylonite sample C38 from the frontal greenschist part was selected for $\mathrm{Ar} / \mathrm{Ar}$ dating, 
whereas a similar sample (P34) yielded metamorphic and hydrothermal zircons $22.0 \pm 4.7$ Ma old [Valli, 2005; Valli et al., submitted].

Frontal greenschist gneisses (C27) of section 3 (Figure 4) pass southwestward to highgrade biotite-rich and two-mica gneisses (P18), and mylonites, inter-layered with sheared leucocratic veins (C30). Leucocratic veins increase in frequency toward the southwest, where leucogranitic pods (C31) invade biotite-rich and two-mica gneisses and lead to a complex set of deformed dykes which are connected to a dextrally sheared leucogranitoid massif (C32). The leucocratic veins are more or less deformed, with the oldest ones transposed in the foliation of the hosting gneisses and highly sheared (see Figure 4d of Lacassin et al., 2004). Strain intensity in the veins increases with decreasing angles between the vein and the foliation in the hosting gneisses. The younger veins crosscut the hosting gneisses foliation with angles up to $90^{\circ}$ (Figure 4c of Lacassin et al., 2004), but still exhibit a slight foliation parallel to the one of the hosting rocks. This indicates that veins emplaced successively during right-lateral shear have been more or less rotated and deformed depending on their age [Lacassin et al., 2004; Valli, 2005]

A concordant fraction of needle-like zircon grains yield the $\sim 23$ Ma crystallization age of the syn-kinematic leucogranitoid C32 [Lacassin et al., 2004; Valli, 2005;]. Zircons and monazites from the hosting biotite-rich and two-mica gneisses indicate that they are orthoderived and crystallized between $\sim 26.8$ and 19.2 Ma (samples P18 and P20 [Valli, 2005; Valli et al., submitted]). The crystallization of monazites occurred between $\sim 19$ Ma and $\sim 16$ Ma, likely during hydrothermal alteration (samples P18 and C32).

Section 4 (Figure 4) is exclusively composed of sheared leucogranitoid. A deformed sample was taken at the southwest end of the section (C43). U-Th-Pb dating of monazites 
and zircons revealed the crystallization of hydrothermal and metamorphic zircons and monazites occurred between $\sim 14$ and $\sim 22 \mathrm{Ma}$.

Outcrop 5 (Figure 2) corresponds to a non-deformed two-mica granitoid (P56, P57).

Section 6 (Figure 4) exhibits intensively fractured migmatites, dextral-normal greenschist two-mica gneisses (P32), and finally a slightly deformed two-mica granitoid crosscut by variously deformed tourmaline-bearing leucocratic veins.

\section{Petro-structural evidence for continuum shearing from high to near surface temperatures}

Rocks are mainly composed of quartz, feldspar and mica; other constituents, proportions and crystal sizes are detailed in Table 1. Samples P56, P57, L86, and L87 are isotropic and present a plutonic texture, they are herein called granitoids. All other samples (L90, L91, $\mathrm{C} 27, \mathrm{C} 30, \mathrm{C} 31, \mathrm{C} 38, \mathrm{C} 43, \mathrm{P} 18, \mathrm{P} 32)$ are deformed to various extents under various temperature conditions .

Feldspar porphyroclasts commonly show recrystallized grains at their boundaries, producing a core-and-rim structure diagnostic of dynamic recrystallization (e.g. [Passchier and Trouw, 1996], Figure 7a). Such dynamic recrystallization strongly depends upon temperature, and to a minor extent on other factors such as strain rate, differential stress, and the chemical activity of certain components such as water [Passchier and Trouw, 1996; White, 1975]. Consistent observations in several natural examples suggest that such dynamic recrystallization occurs at medium- to high-grade temperature conditions $\left(>600-400^{\circ} \mathrm{C}\right)$ during deformation, (e.g. [Gapais, 1989a; 1989b; Leloup et al., 1995; Passchier and Trouw, 1996]). Other deformation characteristics in feldspar indicate that deformation continued 
under retrograde conditions. Abundant myrmekite growth along the boundaries of K-feldspar porphyroclasts (Figure 7b), especially at high stress sites, suggests a deformation under medium-grade temperature conditions $\left(400-600^{\circ} \mathrm{C}\right.$, [Borges and White, 1980; Gapais, 1989a; 1989b; Gates and Glover, 1989; Passchier and Trouw, 1996; Simpson and Wintsch, 1989; Tsurumi et al., 2003; Tullis and Yund, 1991]). Bent twin lamellae (Figure 7c), undulose extinction, and kink bands suggest deformation under lower-grade temperature conditions (300-400 ${ }^{\circ}$ C, e.g. [Gower and Simpson, 1992; Jensen and Starkey, 1985; Ji and Mainprice, 1990; Olesen, 1987; Olsen and Kohlstedt, 1985; White and Mawer, 1986]). Finally, brittle deformation of porphyroclasts, often in the form of "bookshelf" microfracturing (samples $\mathrm{C} 30, \mathrm{P} 32)$, and, in place, patchy undulose extinction indicates even lower-grade conditions (below $300^{\circ} \mathrm{C}$; [Passchier, 1982; Passchier and Trouw, 1996; Tullis and Yund, 1987]) during late increments of deformation.

Dynamic re-crystallization through subgrain rotation (Figure 8a) or grain boundary migration (Figure 8b) occurs in quartz [Guillopé and Poirier, 1979; Passchier and Trouw, 1996; Tullis and Yund, 1991]. These structures are typical at medium to high-grade conditions (700-400 ${ }^{\circ} \mathrm{C}$, [Hirth and Tullis, 1992; Passchier and Trouw, 1996]). Quartz grains also exhibit undulose extinctions typical of low-grade conditions below $300^{\circ} \mathrm{C}$ [Passchier and Trouw, 1996] during late deformation stages.

Mica fish are thought to form due to combined slip on the basal plane, rigid body rotation, boudinage and re-crystallization at the edges [Eisbacher, 1970]. These mechanisms imply deformation at temperature higher than $\sim 250^{\circ} \mathrm{C}$ [Stesky, 1978; Stesky et al., 1974]. Micas also show characters typical of very low-grade metamorphism below $\sim 250^{\circ} \mathrm{C}$, such as undulose extinction and, in some samples, kinking and folding (P36, C43, [Stesky, 1978; Stesky et al., 1974]). 
The different temperature-dependent deformation mechanisms described above produce asymmetric microstructures indicating the sense of shear. Sigmoidal and $\delta$-type feldspars, quartz subgrains rotation and re-crystallization, myrmekite formation at high stress sites, and asymmetric mica 'fishes' all indicate the same unambiguous dextral shear sense on NE dipping foliations, or top to the south shear in samples with flatter foliation planes. Such dextral and top to the south shear thus appears to have been continuous from temperature higher than $400-600^{\circ} \mathrm{C}$ down to low-grade conditions of $<250^{\circ} \mathrm{C}$.

\section{Analytical methods}

\section{1. ${ }^{40} \mathrm{Ar}-{ }^{39} \mathrm{Ar}$ techniques}

Minerals were separated using heavy liquids, a Frantz magnetic separator and finally by hand picking under a binocular microscope. The samples were irradiated at the Phoenix Memorial Laboratory reactor of the University of Michigan, in the L67 position for $20 \mathrm{~h}$ with

a $10^{18}$ neutrons $\mathrm{cm}^{-2} \mathrm{~s}^{-1}$ flux. Irradiation interference on $\mathrm{K}, \mathrm{Ca}$ and $\mathrm{Cl}$ were corrected by irradiating and analyzing $\mathrm{KCl}$ and $\mathrm{CaF}_{2}$ pure salts. $\mathrm{J}$ factors were estimated by the use of duplicates of the Fish Canyon sanidine standard with an age of $28.48 \mathrm{Ma}$ [Schmitz and Bowring, 2001; Schmitz et al., 2003].

The samples were analyzed in Clermont-Ferrand (samples L90, L91, L86, C38, C27, C29, C30, C31, C43) and Montpellier (samples P32, P56 and P57) using the same apparatus and the same protocol, as described in [Arnaud et al., 2003]. Samples were loaded in aluminum packets into a double vacuum Staudacher type furnace and step heated; temperature is calibrated by means of a thermocouple. The gas was purified using cold traps 
with liquid air and Al-Zr getters. Once cleaned, the gas was introduced into a VG3600 mass spectrometer and allowed to equilibrate for 2 min prior to analysis was done statically. Signals were measured by the mean of a Faraday cup with a $10^{11} \mathrm{ohm}$ resistor for ${ }^{40} \mathrm{Ar}$ and ${ }^{39} \mathrm{Ar}$ while ${ }^{39} \mathrm{Ar},{ }^{38} \mathrm{Ar},{ }^{37} \mathrm{Ar}$ and ${ }^{36} \mathrm{Ar}$ were analyzed with a photomultiplier after interaction on a Daly plate. Gain between both collectors was estimated by duplicate analysis of ${ }^{39} \mathrm{Ar}$ on both collectors during each analysis, and also by statistical analysis over a period of several years. This gain is 95 and is know at better than $1.5 \%$. This error is included in the age calculation, along with analytical errors on each signal and errors on the blank values. Detailed analytical results are available as electronic supplements. Age plateau given are weighted mean plateaus; the error takes the error on the $\mathrm{J}$ factor into account. With the historical decrease of analytical errors, strict plateau criteria [Berger and York, 1981; Dalrymple and Lanphere, 1974] are less frequently met. Thus, pseudoplateaus are used when a significant number of steps overlap globally at $2 \sigma$ even if contiguous steps do not. For Kfeldspars, plateau ages cannot be defined, but since we wish to compare and discuss series of steps with similar ages we used simple mean, thus unweighted, ages. Isochron ages are obtained on an inverse isochron diagram of ${ }^{36} \mathrm{Ar} /{ }^{40} \mathrm{Ar}$ versus ${ }^{39} \mathrm{Ar} /{ }^{40} \mathrm{Ar}$ [Roddick, 1978; Roddick et al., 1980], which often allows homogeneous excess components to be identified. Errors on age and intercept age include individual errors on each point and linear regression by York's method [1969]. The goodness of fit relative to individual errors is measured by Mean Square Weighted Deviation (MSWD).

For micas, classical furnace step heating was conducted and usually yielded an almost perfectly flat age spectra, from which plateau and isochron ages were calculated and are shown side by side to assess potential excess argon problems. If the inverse isochron age is close to the plateau age and ${ }^{40} \mathrm{Ar} /{ }^{36} \mathrm{Ar}$ is not significantly different from present day ${ }^{40} \mathrm{Ar} /{ }^{36} \mathrm{Ar}$ 
atmospheric ratio (295.5), we consider that the plateau age is reliable. When this is not the case, we suspect a non-atmospheric initial ${ }^{40} \mathrm{Ar} /{ }^{36} \mathrm{Ar}$ ratio and we thus prefer to rely on the inverse isochron age if this one is well determined.

A more peculiar step-heating schedule was conducted on K-feldspar in order to retrieve diffusion characteristics, to apply diffusion models, and to calculate model thermal histories [Harrison et al., 1991; Lovera et al., 1989; 1991]. We conducted duplicated isothermal step heating at low temperatures $\left(450-800^{\circ} \mathrm{C}\right)$; these often yield a sawtooth-shaped age spectrum where the second of the two stages is systematically younger and probably less affected by excess argon (e.g., [Harrison et al., 1994]). The use of pseudoplateaus or isochrons on series of steps on K-feldspars may seem at odds with the classical definitions. However K-feldspars are known to be composite and also to record, in certain conditions, cooling histories and especially rapid cooling events, which are theoretically, marked by flat portions of the age spectra [Lovera et al., 1989, 1991]. Those portions can be treated by statistical approaches (such as plateaus and isochrons) and can be interpreted as revealing undisturbed quenched parts of the sample or alternatively the presence of excess argon. All errors are quoted at 2 sigmas.

\subsection{U-Th-He techniques}

We used euhedral apatite grains that were checked for inclusions under a binocular microscope. Grain dimensions were measured under a microscope to determine the $\alpha$ emission correction [Farley et al., 1996]. All replicates where loaded in platinum capsules and heated for He extraction by laser for 5 minutes at $\sim 1050{ }^{\circ} \mathrm{C}$ following the procedures described by [House et al., 2000]. Packets were then transferred into Teflon beakers for 
dissolution before being analyzed with a Finnegan Element ICP-MS (see [House et al., 2000] for detailed analytical procedure). The mean age is reported as there were three replicate analyses (Table 2). Propagated errors on He ages based on the analytical uncertainty in $U$, Th, and He measurements are 2\% (1-sigma) for laser samples [Farley, 2002]. However the propagated error from geometrical correction of ages as well as intrinsic heterogeneities in $\mathrm{U}$ content usually lead to much higher errors. Farley [2002] suggests a minimum uncertainty of $3 \%$ (1-sigma) for all ages, based on the reproducibility of laboratory standards. Mean error is reported at 1-sigma as standard errors using the standard deviation of the replicate analyses divided by $(n-1)^{1 / 2}$ where $n$ is the number of replicate analyses performed (Table 2). This error estimate is larger than the analytical error alone and likely reflects the age uncertainty due to differences in grain size, zoning of parent material and other factors which may contribute to grain differences in He age and uncertainties in the alpha-ejection correction [i.e., House et al., 2001].

\subsection{Apatite fission track (AFT) methodology}

Apatite was separated using standard magnetic and density methods, then mounted on glass slides with araldite epoxy. After grinding and polishing to expose an internal surface, the apatites were etched with 5.5 molar nitric acid for 20 seconds at $21^{\circ} \mathrm{C}$. Samples were irradiated at Oregon State University. After irradiation, mica external detectors were etched in $40 \% \mathrm{HF}$ for 45 minutes at $21^{\circ} \mathrm{C}$. For age determinations, 20 to 23 good-quality grains per sample were selected at random and dated using the external detector method. Laboratory procedures are essentially the same as those reported in [Sobel and Strecker, 2003]. 
At temperatures hotter than $\sim 110-150^{\circ} \mathrm{C}$, all fission tracks are totally annealed, resetting the fission track clock to zero. The total annealing temperature $\left(\mathrm{T}_{\mathrm{A}}\right)$ and the effective closure temperature depend on the kinetic characteristics of the apatite and the cooling rate [Ketcham et al., 1999]. The partial annealing zone (PAZ) extends from the $\mathrm{T}_{\mathrm{A}}$ down to $\sim 60^{\circ} \mathrm{C}$, and within this temperature range tracks are partially annealed. Below $\sim$ $60^{\circ} \mathrm{C}$, AFT are effectively stable because annealing occurs at a very slow rate [e.g. Gleadow et al., 1986]. Following convention, all statistical uncertainties on pooled ages and mean track lengths are quoted at the $\pm 1 \sigma$ level, but $\pm 2 \sigma$ uncertainties are taken into account for geologic interpretation.

\section{Analytical results}

\subsection{K-feldspar}

The shapes of all age spectra are roughly similar, with a first low temperature (LT) pseudoplateau between $\sim 10-40 \%$ of gas release corresponding to furnace temperature below $700^{\circ} \mathrm{C}$, followed by a rapid age increase toward a high temperature (HT) plateau or pseudoplateau (Table 3, Figure 9a, and Appendix A).

The youngest steps on K-feldspar LT ages (L90, L91, C27, C30, C38, C43, P32, P57), or pseudoplateaus (C31, P56) defined on K-feldspar LT steps, appear diachronous between the northernmost section and other localities: two samples from section (1) yield ages at 14$12 \mathrm{Ma}$, whereas in other sections (2, 3, 4, 5 and 6), the eight K-feldspar samples invariably exhibit LT pseudoplateau age in a range of $\sim 10-7$ Ma. Inverse isochron diagrams on the same LT steps often revealed slight excess argon, in agreement with most studies revealing 
excess argon release from K-feldspars at low temperature due to fluid inclusion breakdown [Burgess et al., 1992; Harrison et al., 1994]. In our case, excess argon had only a minor effect since the isochron age estimates are similar to the pseudoplateau ones when considered at the $2 \sigma$ confidence level.

The HT K-feldspar age plateau (L90, L91, C30, C31, C38, C43), or pseudoplateau (C27), yield a relatively wide range of average ages from $21.2 \pm 1.0$ to $15.3 \pm 0.7 \mathrm{Ma}$ (Table 3), with no correlation with the geographic position of the samples. Most corresponding inverse isochron diagrams yield relatively scattered data (Fig. 9, Appendix A), preventing any reliable isochron age calculations (MSWD > 30). Only for sample C38 an HT isochron age of $17 \pm 1 \mathrm{Ma}$ can be calculated $\left({ }^{40} \mathrm{Ar} /{ }^{36} \mathrm{Ar}_{\mathrm{i}}=420 \pm 90\right)$ that is not statistically different from the HT Simple Mean Age (Table 1). The high temperature steps of the P32, P56 and P57 Kfeldspar age spectra have partially scattered ages and do not present reliable plateau or pseudoplateau ages; it was thus impossible to get reliable age estimates or perform thermal modelling on those samples. Locally, older spikes appear on all the increasing middle temperature part of the spectra, but they are relatively minor and were neglected for modelling.

\subsection{Micas}

Muscovite and biotite age spectra are charactistically flat for most of the gas release (Tables 4 and 5, Figures $9 \mathrm{~b}$ and 9c, Appendix B and C, respectively). Inverse isochron diagrams reveal that the ${ }^{40} \mathrm{Ar} /{ }^{36} \mathrm{Ar}$ i is systematically close to the atmospheric composition; consequently, inverse isochron ages, plateau ages, and total fusion ages are identical. 
Like LT feldspar ages, mica ages are diachronic between the northernmost section (1) and the other sections. In valley (1), white mica ages are $15.4 \pm 0.3-14.4 \pm 0.3 \mathrm{Ma}$, whereas biotites recorded an age of $14.3 \pm 0.3 \mathrm{Ma}$; micas from other sections $(2,3,4,5,6)$ provide constant ages lying in a narrow range of $12.7 \pm 0.2-10.4 \pm 0.8 \mathrm{Ma}$ for muscovite, and $11.9 \pm$ $0.3-10.8 \pm 0.7 \mathrm{Ma}$ for biotite.

\subsection{U-Th-He on apatite}

Three replicates, each containing four apatite grains from sample P32 (section 5), were analyzed. Replicates gave relatively good reproducibility (the standard deviation represents less than $14 \%$ of the apatite age). Age estimates are comprised between $\sim 4.8$ and $3.7 \mathrm{Ma}$ with a mean value of $4.4 \mathrm{Ma}$ (Table 5). Calculated mean error is $0.4 \mathrm{Ma}$ and analytical uncertainties $<0.1 \mathrm{Ma}(1 \sigma)$. In the following, only the mean error value based on the samples' reproducibility will be used.

\subsection{Fission tracks on apatite}

Samples P18 and C32, from the frontal part of valleys 2 and 5, yield ages of $5.4 \pm 0.4$ and $5.5 \pm 0.6 \mathrm{Ma}$, respectively, whereas sample L87, located $10 \mathrm{~km}$ southwestward of the frontal part of section 1 , shows an age of $8.5 \pm 0.5 \mathrm{Ma}$ (Table 6). Pooled ages are reported as all samples pass the chi-squared test. Sample L87 yielded 25 confined track-lengths; although normally a larger number are utilized for modelling, an average of 3 tracks/Ma is sufficient to permit moderate resolution thermal modelling using the AFTSolve model 
[Ketcham et al., 1999]. The kinetic characteristics of the apatite in this sample were constrained using etch pit diameter measurements (Dpar), calibrated against reported Durango apatite [Ketcham et al., 1999]; a value of $1.55 \mu \mathrm{m}$ was used. The $\mathrm{T}_{\mathrm{A}}$ for this sample is ca. $130^{\circ} \mathrm{C}$.

\section{Constructing a cooling history}

\subsection{Closure temperatures and cooling paths}

Once the age of a given mineral is calculated, a fundamental and controversial issue is to determine whether this age corresponds to mineral crystallization, re-crystallization, or cooling below a given closure temperature. The temperatures estimates for ductile deformation are above $350-400^{\circ} \mathrm{C}$; higher than closure temperatures for the radiogenic systems used in this study. Therefore, ${ }^{40} \mathrm{Ar} /{ }^{39} \mathrm{Ar}, \mathrm{AFT}$ and $\mathrm{U}-\mathrm{Th} / \mathrm{He}$ ages most likely correspond to cooling ages, and we choose to systematically build cooling histories from our results. This choice leaves open further discussion on the internal consistency of such cooling histories and the relationship between ${ }^{40} \mathrm{Ar} /{ }^{39} \mathrm{Ar}$ ages and deformation events. For example, ${ }^{40} \mathrm{Ar} /{ }^{39} \mathrm{Ar}$ ages of the finest white micas may in fact correspond to the age of synkinematic crystallization (e.g., [Kirschner et al., 1996]). We assumed closure temperature of $390 \pm 45^{\circ} \mathrm{C}$ for the white micas ([Hames and Bowring, 1994] and references therein), $320 \pm$ $40^{\circ} \mathrm{C}$ for biotites (e.g., [Harrison et al., 1985]), $115 \pm 15^{\circ} \mathrm{C}$ for the AFT (when thermal modelling was not possible, [Gleadow et al., 1986; Ketcham et al., 1999]), and $80 \pm 20^{\circ} \mathrm{C}$ for the U-Th/He on apatite [Farley, 2000]. 
Most K-feldspar data permitted modelling of their cooling history. We restricted our models to the simplest possible solution: monotonic cooling. Allowing transit reheating would lead to significantly different but less constrained thermal histories. Modelling was performed on $7 \mathrm{~K}$-feldspar fractions. Modelled age spectra are shown on figure 9 and in appendix A and cooling histories are presented on Figures 10a and 10c. The experimental Arrhenius diagrams were satisfactorily fit with diffusion models assuming 5 to 8 domains sharing common activation energy on the order of 33.5-39.9 Kcal/mol. The best cooling models invariably show two rapid cooling phases separated by an isothermal or slow cooling rate period. The age of the oldest cooling event varies over a wide range of $\sim 23-14 \mathrm{Ma}$ in relation with the variability of HT ages in K-feldspars, but these ages are poorly constrained, since it was impossible to obtain a perfect fit for the oldest part of the age spectrums (Figure 9, and Appendix A). Moreover the modelling is based on the assumption that argon diffuses out of the lattice, while within the furnace, breakdown of the feldspars takes place in the range $1050-1100^{\circ} \mathrm{C}$, thus violating the model hypothesis above these temperatures. Modelling above $1100^{\circ} \mathrm{C}$ is therefore unconstrained. Following cooling from high temperature a period of slow cooling rate $\left(<15^{\circ} \mathrm{C} / \mathrm{Ma}\right)$ is modelled and corresponds to a drop of temperature down to $\sim 210-260{ }^{\circ} \mathrm{C}$. The youngest cooling event is always very well constrained at $\sim 12 \mathrm{Ma}$ for samples of the northernmost valley (section 1 ) and at $\sim 11-9 \mathrm{Ma}$ for all the others (sections 2, 3, 4).

\subsection{Pertinence of the cooling models from K-feldspars}

The time-temperature diagram reveals an incompatibility between the K-feldspar timetemperature modelling and the rest of the data set: all but L91 K-feldspar cooling curves, and 
especially the protracted slow cooling periods, do not match the mica ages if classical mica closure temperature are accepted (Figures 10a, 10c). It is noteworthy that the white mica ages of dextrally deformed samples (L90, L91) from valley 1 are identical to those of white micas coming from a non-deformed sample (L86) located in the same valley. Similarly, consistent biotite ages determined from deformed samples of valleys 4 and 6 are contemporaneous with non-deformed biotite ages from samples located in valley 5 (P57, P56). This strongly suggests that the micas crystallized prior to the last deformation increments, and thus not below their closure temperature, ruling out exceptionally low temperatures that would bring the mica ages down on the feldspar cooling curve. Therefore, micas ${ }^{40} \mathrm{Ar}{ }^{39} \mathrm{Ar}$ ages most likely represent cooling ages at "normal" closure temperature. Similarly, there is no reason to suspect abnormally high kinetic characteristics in the feldspars that would imply that the less retentive domains closed at higher temperature around 11-9 Ma. Our calculated activation energies 33.5-39.9 Kcal/mol are on the low side compared with the statistical study of Lovera et al. [1997], which showed that feldspars from various origins and terrains have activation energies varying around a mean of ca $46 \pm 6$ $\mathrm{kcal} / \mathrm{mol}$. However, even activation energies of $50 \mathrm{kcal} / \mathrm{mol}$ would not imply closure temperatures high enough to reconcile feldspars and mica data.

On the other hand, petro-structural observations show significant syn-kinematic recrystallization of K-feldspar with the development of a mantle of re-crystallized grains around crystal cores. Thus, the dated K-feldspars were most likely constituted of clusters made of several generations of intimately mixed crystals having grown, crystallized and cooled at various times during the deformation rather than monogenetic single crystals with simple diffusion domains. This strongly suggests that thermal models are not reliable in that case. 
Since thermal modelling using simple diffusion and monotonic cooling does not adequately explain the continuous re-crystallization of the dated phases, we therefore used a cruder approach, assuming accepted closure temperatures for micas. Since pseudoplateaus exist for both LT and HT ages, it is likely that argon loss was limited at the corresponding times. This implies that rapid cooling took place at those periods, pointing to a limited closure temperature window at those times. We also make the hypothesis that, although the kinetic characteristics calculated from the continuous thermal modelling of feldspars are not adequate to be used for a single grain, they can be used as crude estimates for the closure temperatures of crystals degassing during LT and HT phases. Using these data suggest that the LT ages correspond to cooling at $\sim 150-300^{\circ} \mathrm{C}$, whereas HT ages (at $1000-1400^{\circ} \mathrm{C}$ furnace temperatures) correspond to cooling at $\sim 300-450^{\circ} \mathrm{C}$ (Figures $10 \mathrm{~b}, 10 \mathrm{~d}$ ) (e.g., Leloup et al, 2001). As it is often difficult to assess which of the isochron or plateau ages is the most realistic because both are equally acceptable statistically, we quote uncertainties that include the entire range of isochron and plateau age estimates, the resulting global uncertainties are taken at the $2 \sigma$ confidence level.

\section{Geochronological constraints on the age of right-lateral shearing and normal faulting along the Ayilari range.}

\subsection{High to medium temperature thermochronological data (argon $\mathrm{HT} \mathrm{Kf}$ ) and (U-Th/Pb) geochronology: evidence for a first Lower Miocene rapid cooling event.}

$\mathrm{U}-\mathrm{Th}-\mathrm{Pb}$ ages obtained by classical Isotopic Dilution - Thermo Ionisation Mass Spectrometry (ID-TIMS) and by Secondary Ion Mass Spectrometry (SIMS) on zircons and 
monazites (Lacassin et al. [2004] and Valli et al. [2005 and submitted]) reveal that the most recent magmatic episode took place at $\sim 25-21 \mathrm{Ma}$ in the Ayilari range. This episode was synkinematic with right-lateral shear and was accompanied and followed by metamorphism from $\sim 22$ to 19 and hydrothermalism between $\sim 22$ and 15 Ma (Valli et al. [2005 and submitted]) (Fig. 11a). These results are interpreted as reflecting heat and fluid advection during deformation along the KFZ. Those ages are very close to or identical within error to the HT ages from K-feldspars of the present study. Theoretically, the granitoid crystallization temperature $\left(\sim 750-800^{\circ} \mathrm{C}\right.$ [Clemens, 2003]) is $\sim 350^{\circ} \mathrm{C}$ above the feldspar HT cooling temperature $\left(\sim 400^{\circ} \mathrm{C}\right)$, (Fig. 11$)$, which should have lead to significantly different ages. Three hypotheses can be envisaged to explain both data sets. (1) K-feldspar HT ages could be too old because of excess argon. However, a close analysis of inverse isochrons show that there is no clear evidence for such excess; the age of the only sample with an HT isochron age is confirmed by the Simple Mean Age (see section 6.1). This strongly suggest that little excess argon is present and that K-feldspar HT ages are meaningful as is the spread in age between samples of $\sim 6$ Ma observed in each section (Figure 10). (2) K-feldspar HT ages could correspond to unusual high closure temperatures. But as discussed in section 7 , there is no reason to suspect such a case. (3) Both magmatic zircon U/Pb and argon $\mathrm{HT} \mathrm{K}-$ feldspars ages are correct and associated with the expected closure temperatures. This implies that the Early Miocene ( 25-21 Ma) syn-kinematic magmatic episode was immediately followed by a period of rapid cooling during which metamorphism took place until $\sim 19$ Ma and metasomatism until $\sim 15$ Ma (Fig. 11). For example, in section 1, temperature dropped from solidus temperature $\left(<750^{\circ} \mathrm{C}\right.$ for two-mica granitoids [Gardien et al., 1995) at 24.2 $\pm 2.4 \mathrm{Ma}$ (L89 magmatic monazite), to closure temperatures corresponding to the HT part of the K-feldspars age spectra $\left(400 \pm 50^{\circ} \mathrm{C}\right)$ at $18.4 \pm 1.3(\mathrm{C} 38$, most reliable $\mathrm{Kf}$ 
HT age), (Figure 11a). Because hydrothermal monazites and zircons can have crystallized in a large range of temperatures $\left(\sim 350-700^{\circ} \mathrm{C}\right.$, [Seydoux et al., 2002] it is not possible to draw more precise cooling histories. For example L89 metamorphic or hydrothermal monazites have the same age than the HT K-feldspar.

Rapid cooling soon after 25-21 Ma could results from tectonic exhumation immediately after the granitoids emplacement and associated with thrust or normal components of displacements along the KFZ at that time. However, in the North Ayilari range all kinematic indicators associated with deformation under high to medium temperature conditions $(>600$ $400^{\circ} \mathrm{C}$ ) indicate an almost pure dextral shear with horizontal lineations (see section 3.1. and Figure 5). Dextral-normal deformation is restricted to the more brittle and recent stages of deformation (see below). A phase of tectonic exhumation coeval with this Early Miocene rapid cooling event is thus unlikely. Alternatively, rapid cooling could follow high temperature shearing at shallow depths. High geothermal gradient due to shear heating and/or heat advection is common in strike-slip shear zones [e.g., Leloup et al., 1999] It may induce fast local cooling when deformation slows-down or ceases at one location, even if it continues in another part of the shear zone. Such process could explain the differences between the various HT K-feldspar ages, as the samples are located at different places within the shear zone. Unfortunately, we do not have good constraints on the depth of right-lateral deformation in the North Ayilari range to confirm this hypothesis.

In the Pangong range 200-350 km to the northwest (Figure 1) outcrop other rightlaterally sheared ductile mylonites [Searle et al, 1998; Dunlap et al., 1998; Rolland and Pêcher ,2001; Rolland, 2002; Rolland et al., in press ]. Dunlap et al. (1998) state that the strike-slip motion is restricted to amphibolite and greenschist metamorphic conditions. However, recent petrologic and thermo-barometric studies constrain the P-T-t path during 
this deformation [Rolland and Pêcher, 2001; Rolland et al., in press]. Both granulitic $\left(\geq 800^{\circ} \mathrm{C}\right.$ and $\left.\sim 5.5-5 \mathrm{~kb}\right)$ and amphibolitic $\left(650^{\circ} \mathrm{C}-6-7 \mathrm{~kb}\right)$ conditions occur. Peak temperature in the amphibolitic rocks were attained at $\sim 18 \mathrm{Ma}$, at the time of Tangtse granite emplacement (Fig. 11b, sample 450 of Rolland et al, in press). As strike-slip deformation continued, temperature dropped to $\sim 500^{\circ} \mathrm{C}$ at $\sim 13.6 \mathrm{Ma}$ (Fig. 11b, sample 441 of Rolland et al, in press) during cooling to low $\mathrm{T}$ amphibolitic conditions $\left(500-300^{\circ} \mathrm{C}\right.$ and $\left.2-5 \mathrm{~kb}\right)$. This suggests that strike-slip deformation at middle to upper crustal levels (depth $\leq 20 \mathrm{~km}$ ) occurs under anomalously high temperature conditions. The shear zone thermal state was probably very similar in the North Ayilari range.

\subsection{Medium to low temperature cooling history of the Ayilari range: evidence for a second} rapid cooling in the Middle Miocene.

Below $400^{\circ} \mathrm{C}$, time-temperature paths can be drawn from argon (muscovite, biotite, LT K-feldspar), apatite fission track and apatite $\mathrm{U}-\mathrm{Th} / \mathrm{He}$ data (Figure 10b, 10d, 11a). These paths show good agreement between the different thermochronometers since, within error, age estimates decrease with the closure temperature of the minerals (Figures 10b, 10d).

At temperature around $400^{\circ} \mathrm{C}$, the $\mathrm{HT}$ parts of the $\mathrm{K}$-feldspars spread in age between 22-15 Ma in section 1 (Figure 10b), and $21-15 \mathrm{Ma}$ in the southern valleys (Figure10d), while muscovite ages are grouped between $\sim 15-14$ Ma and 13-12 Ma, respectively (Figures $10 \mathrm{~b}, 10 \mathrm{~d})$. These suggest cooling rates lower than $14^{\circ} \mathrm{C} / \mathrm{Ma}$ during the $\sim 22-14$ Ma period in section 1 , and lower than $10^{\circ} \mathrm{C} / \mathrm{Ma}$ during the $\sim 21-12$ Ma period in the southern valleys. The flatness of mica plateaus (Figures 9b, 9c, and Appendix B-C) is atypical for gneisses or granitoids; it is more characteristic of rocks in which crystals were quenched. This, together with the narrow age difference between muscovite and biotite, strongly suggests the 
initiation of rapid cooling at $\sim 15-14 \mathrm{Ma}$ in the northernmost section, and at $\sim 13-12 \mathrm{Ma}$ in the other sections. The thermochronometric estimates, in the time period $\sim 15-5 \mathrm{Ma}$ for section 1 , and $\sim 13-4$ Ma for the other sections, suggest monotonic rapid cooling at an average rate of $\sim 40^{\circ} \mathrm{C} / \mathrm{Myr}$ and $\sim 36^{\circ} \mathrm{C} / \mathrm{Myr}$, respectively (Figures $10 \mathrm{~b}, 10 \mathrm{~d}$ ). This second episode of rapid cooling is clearly associated with petrostructural indicators of medium to low temperature, indicating the onset of a component of normal throw on the Karakorum fault in the Gar basin. This kinematic change induced exhumation and faster cooling and was probably associated with the rise of the Ayilari range.

In summary petrostructural data not only show that deformation with a dextral component of shear started at temperature $>400-600^{\circ} \mathrm{C}$, but also that it has been continuous up to near-surface conditions, and was thus associated to the cooling history deduced in the $21-\leq 4 \mathrm{Ma}$ age range. Our thermochronological results reinforce and extend our previous conclusions [Lacassin et al., 2004; Valli, 2005; Valli et al., submitted], now demonstrating not only that right-lateral motion was already in progress in the early Miocene $(25-21 \mathrm{Ma})$ but also that right-lateral shear with a normal component initiated at 12-15 Ma and continued until at least 4 Ma. Since such deformation is still active [e.g., Armijo et al., 1989; Chevalier at al., 2005], this implies at least 20 million years of deformation along the southern part of the Karakorum Fault zone.

\section{Large-scale geometry and kinematics of the Karakorum fault zone.}

\subsection{Large-scale kinematics of the $\mathrm{KFZ}$}


Along the entire KFZ, the crystallization ages of numerous granitoids which are likely syn-kinematic, as well as thermochronological ages $\left({ }^{40} \mathrm{Ar} /{ }^{39} \mathrm{Ar}\right.$, Fission tracks, U-Th-He) of cooling coeval with dextral shear, also suggest an early onset of deformation along the KFZ.

As already mentioned, dextrally sheared mylonites of the KFZ also outcrop in the Pangong range and in the Nubra valley (Fig. 1). In the Pangong range, a $\sim 6 \mathrm{~km}$ wide band of mylonitized leucogranites, migmatites, amphibolitic and granulitic gneisses outcrop in between two strands of the KFZ [Searle et al., 1998, Rolland et al., in press]. U/Pb shrimp zircon ages of $18.0 \pm 0.6$ (sample 215) and $18.5 \pm 1.5$ (sample O22) were interpreted as dating crystallization of the Tangtze granite [Searle et al., 1998]. Mylonitic leucogranites from Tangtze and Nubra yield $\mathrm{U} / \mathrm{Pb}$ ages of $\sim 16 \mathrm{Ma}$ (samples P1, P11, P38 [Phillips et al., 2004],), while cross-cutting dykes yield ages of $\sim 14 \mathrm{Ma}$ (samples P8 \& P37, [Phillips et al., 2004]), (Fig. 11b) Such ages are interpreted to bracket the time of initiation of right-lateral faulting along the KFZ because ductile deformation is considered to have started after granite crystallization and have ended prior to leucocratic veins emplacement [Phillips et al., 2004]. While such ages dismiss the idea of a purely Holocene KFZ, as proposed by Searle [1996] on a regional basis, they imply a younger onset than the $\geq 21 \mathrm{Ma}$ age proposed in the Ayilari range [this study; Lacassin et al., 2004; Valli et al., submitted].

Several lines of evidence suggest that the Tangtse granite is syn-kinematic to the KFZ and thus that $\sim 18$ and $\sim 16 \mathrm{Ma}$ are only lower bounds, not upper bounds, for the age of this fault. (1) As already emphasised for the North Ayilari range (section 2-2, Fig. 5d) the emplacement of a network of variously deformed dykes which come together to form a main sheared pluton represent reliable field evidence of syn-kinematic crystallization [Lacassin et al., 2004a]. Such field relationships correspond to the Tangtse granite and associated dykes [Philips et al., 2004; Searle et al., 1998; Weinberg and Searle 1998]. (2) S-C fabrics are 
ubiquitous in the North Ayilari range (Fig. $5 \mathrm{~b} \& \mathrm{c}$ ), and in the Tangtse granite [Rolland, 2000; Searle et al., 1998]. Such structures are typical of shear deformation under high to medium-grade temperature conditions, and they might be typical of syn-kinematic granitoid [e.g., Gapais, 1989a; 1989b; Gapais and Barbarin, 1986]. The deformed rocks indeed show clear evidence for the re-crystallization of feldspar and quartz, the latter by subgrain rotation and grain boundary migration (Figure 8 of [Searle et al., 1998], and [Rolland, 2000]), demonstrating that strike-slip deformation occurred at temperature above $600-400^{\circ} \mathrm{C}$ (see section 2-3). Such temperatures are close to the $750^{\circ} \mathrm{C}$ solidus temperature of two micabearing granites and dykes [Gardien et al., 1995, and references therein]. This suggest that crystallization of the Tangtse granite might have been syn-kinematic. The possibility of high temperature $\left(>350-\leq 750{ }^{\circ} \mathrm{C}\right)$ strike-slip deformation was already evoked by Dunlap et al. [1998] (p904), and Weinberg and Searle [1998] (p885 and 890). (3) The Tangtse granite is intrusive within granulitic and amphibolitic rocks. The P-T path of these rocks is retrograde from granulitic $\left(\mathrm{T}>800^{\circ} \mathrm{C}, \mathrm{P} \sim 5.5 \mathrm{~Kb}\right)$ or amphibolitic $\left(\mathrm{T} \sim 750-700^{\circ} \mathrm{C}, \mathrm{P} \sim 4-5 \mathrm{~Kb}\right)$ to greenschist $\left(\mathrm{T} \sim 500^{\circ} \mathrm{C}, \mathrm{P} \sim 3 \mathrm{~Kb}\right)$ conditions [Rolland and Pêcher, 2001; Rolland et al., in press]. These host rocks were penetratively deformed in a dextral transpressive environment at temperature ranging from $>800^{\circ} \mathrm{C}$, thus above the Tangtse granite solidus temperature $\left(750^{\circ} \mathrm{C}\right)$, to surface conditions. This again suggests a syn-kinematic emplacement of the granite.

One may speculate that other granitoids along the fault may also be used as evidence for syn-tectonic magmatism and metamorphism. Farther to the NW, the Baltoro batholith crystallized between 26 and 20 Ma [Parrish and Tirrul, 1989; Schärer et al., 1990], at relatively low temperature $\left(750-600^{\circ} \mathrm{C}\right)$ [Searle et al., 1992]. The batholith has a sigmoidal 
shape; the southern and northern edges strike $\sim \mathrm{N} 110^{\circ}, 100 \mathrm{~km}$ west of the $\mathrm{KFZ}$ and progressively bends eastward to become parallel to the KFZ (N142 ${ }^{\circ}$ strike, Fig. 1). South directed thrusting occurred during granite emplacement along the southern edge of the batholith [Searle et al., 1992]. The eastern border of the batholith is crosscut by the KFZ active strand and shows dextral S-C structures [Searle et al., 1998]. Similar to the Tangtse granite, the Baltoro batholith has been interpreted as predating the onset of dextral motion along the KFZ [Searle, 1996; Searle et al., 1998]; however, its large-scale sigmoid shape suggests an intrusion synchronous with right-lateral deformation along the KFZ, coeval with thrusting on the batholith southern edge and dextral high to medium temperature deformation along its eastern border. In this case, the 26-20 Ma ages of the batholith would, as already suggested by Mahéo et al. [2004], represent a lower bound for the initiation of the KFZ.

In the Pangong range, Dunlap et al. [1998] report two phases of rapid cooling, one at ca.17-13 Ma followed by an intervening period of relatively slow cooling, and the second starting at ca. $8 \mathrm{Ma}$ and continuing until at least $7 \mathrm{Ma}$ [Dunlap et al., 1998] (Fig. 11b). This time-temperature evolution was mainly based on K-feldspar models, which, as in the Ayilari range, are barely consistent with micas ${ }^{40} \mathrm{Ar}-{ }^{39} \mathrm{Ar}$ ages from the same samples, or from the same structural unit. This suggests that these K-feldspar thermal models are no more reliable than ours. However, a cautious interpretation of the data, assuming that the mica and amphibole ${ }^{40} \mathrm{Ar}-{ }^{39} \mathrm{Ar}$ ages correspond to cooling ages, shows that a single monotonic cooling history cannot perfectly reconcile the entire data set (Figure 11b), as is the case in the Ayilari range, suggesting that the shift in cooling rates at ca $8 \mathrm{Ma}$ is real. . This rapid cooling event occurred during right-lateral transpression [Dunlap et al., 1998; Rolland, 2000; 2002; Rolland and Pecher, 2001], whereas the contemporaneous rapid cooling event recorded in 
the Gar-Baer basin (between $\sim 16-12$ and $<4 \mathrm{Ma}$ ) is associated with transtension [this study; Lacassin et al., 2004; Valli et al., submitted],

The shift from transpression to transtension along the fault could be explained by "zipper tectonics" [Harrison et al., 1996]), a model thoroughly documented along another major continental strike-slip fault: the Ailao Shan - Red river shear zone [Leloup et al., 2001]. If the KF was a transform fault in the strictest sense, it would follow a small circle of the Euler rotation pole between the Ladakh and Qiangtang blocks. Motion would be purely strike-slip and there would be only local denudation along the fault zone in restraining or releasing bends. On the other hand, if the fault does not follow a small circle, transpression and transtension would take place along large portions of the faults; in the NW and SE parts of the right-lateral KFZ if the rotation pole is located NE of the fault. The neutral point that corresponds to the place where the fault zone aligns with a small circle is the only place where motion is purely strike slip and would be located somewhere between the Pangong and Ayilari ranges, thus allowing transtension in the Gar-Baer basins and transpression in the Pangong range and to the north. Since these ranges underwent a strike-slip deformation with only minor denudation prior to $18-12 \mathrm{Ma}$, a regional kinematic change may have occurred at that time, possibly related to blocks readjustments linked to the initiation of the left lateral Gozha fault which formed the northern boundary of the Pangong range (Fig.1). It should be emphasized that this model remains highly hypothetical because of the scarcity of well constrain time-temperature paths along the KF and within adjacent blocks.

\subsection{Formation of the Gar pull-apart basin and hints of long-term slip rate of the KFZ.}

The exhumation of the Ayilari range by normal faulting along its northeastern edge was 
probably associated with the development and deepening of the Gar and Baer pull-apart basins concurrent with the rise of the regional topography. This drove the incision and entrenchment of major river courses that flow in these basins, most notably that of the Indus River (Figure 12a). Likely, the gorges that permit to the Indus River to flow across the Ayilari range date back to the time of rapid uplift of this range at 15-12 Ma, as suggested by our thermochronological data. Matching this outflow channel of the Indus with an upstream inflow channel will thus give an offset accrued in the last 12 to 15 Myrs. If this offset correspond to the present day $120 \mathrm{~km}$ offset of the Indus River course along the northern branch of the KFZ (Figure 12b) this would imply dextral motion at a minimum long-term average rate of $9 \pm 1 \mathrm{~mm} / \mathrm{yr}$ (Figure 12b). Such a reconstruction also implies that the river now flowing in the Bangong lake was the upstream part of the Shyok river 14 Ma ago.

However, as with most major rivers crossing active faults, the present day offset probably represents only a lower bound of finite motion along the northern branch of the KFZ [Gaudemer et al., 1989], because the watershed of the Indus River could have been highly modified during the last millions of years. In the Middle Miocene, this river possibly flowed on the southern side of the Kailas range, where the Gangrinboche molasses were deposited [Davis et al., 2004; Gansser, 1964; Miller et al., 2000], implying a much larger offset of $\sim 280 \mathrm{~km}$ (Figure 12c). In this scenario, after the Indus river started to entrench across the rising Ayilari range (15-12 Ma), the dextral offset of its upstream and downstream channels forced the river to flow along the fault, in a way similar to the actual Gar River. Thrusting in the Kailas area [Yin et al., 1999]. might have started to change the watershed of the Indus River at ca $\sim 13 \mathrm{Ma}$ The actual upstream channel and watershed of the Indus river, which presently flows from the Shiquanhe basin, might have been captured only recently $\sim 10 \mathrm{~km}$ south of Zhaxigang. Taking into account such a hypothetical scenario (Figure 12c) 
would bring the estimate of the long-term average rate on the northern branch of the KFZ to $20 \pm 3 \mathrm{~mm} / \mathrm{yr}$.

For comparison, the total long term offset on the two branches of the KFZ is estimated at 280 to $400 \mathrm{~km}$ from the offset of the Shyok and Indus suture zones [Lacassin et al., 2004], corresponding to average rates of $12 \pm 1$ to $17.5 \pm 1.5 \mathrm{~mm} / \mathrm{yr}$ assuming fault initiation between 25 and 21 Ma ago.

\section{Acknowledgments}

Fieldwork was supported by the programs "Intérieur de la Terre" (IT) and "Dynamique et Evolution de la Terre Interne (DYETI) of CNRS-INSU and by the Institute of Geology, Chinese academy of Geological Sciences, Beijing, China. We thank Mike Murphy and Yann Rolland, and an unknown reviewer for their useful comments, which significantly improved this manuscript. 


\section{References cited}

Armijo, R., P. Tapponnier, J. L. Mercier, and H. Tonglin (1986), Quaternary extension in southern Tibet : field observations and tectonic implications, J. Geophys. Res., 91 (14), 13,803-13,872.

Armijo, R., P. Tapponnier, and H. Tonglin (1989), Late Cenozoic right-lateral strike-slip faulting in southern Tibet, J. Geophys. Res., 94 (B3), 2787-2838.

Arnaud, N. O. (1992), Apports de la thermochronologie 40Ar/ 39Ar sur feldspath potassique a la connaissance de la tectonique cenozoique d'Asie; etude des mecanismes d'accomodation de la collision continentale, Géochimie, PhD thesis, $161 \mathrm{pp}$, Clermont-Ferrand 2, Blaise Pascal, Clermont-Ferrand, France.

Arnaud, N., P. Tapponnier, F. Roger, M. Brunel, U. Schärer, Wen Chen, and Zhiqin Xu (2003), Evidence for Mesozoic shear along the western Kunlun and Altyn-Tagh fault, northern Tibet (China), J. Geophys. Res., 108 (B1), Art. No. 2053.

Avouac, J. P., and P. Tapponnier (1993), Kinematic model of active deformation in central Asia, Geophys. Res. Lett., 20 (10), 895-898.

Berger, G., W., and D. York (1981), Geothermometry from 40Ar/39Ar dating experiments, Geochem. Cosmochem. Acta 45, 795-811.

Borges, F. S., and S. H. White (1980), Microstructural and chemical studies of sheared anorthosites, Roneval, South Harris, J. Struct. Geol., 2, 273-280.

Brown, E. T., R. Bendick, D. L. Bourlès, V. Gaur, P. Molnar, G. M. Raisbeck, and F. Yiou (2002), Slip rates of the Karakorum fault, Ladakh, India, determined using cosmic ray exposure dating of debris flows and moraines, J. Geophys. Res., 107.

Burg, J. P. (1983), Tectogénèse comparée de 2 segments de chaîne de collision: Le sud Tibet (suture du Zangbo) et la chaîne Hercynienne en Europe (Massif Central Français), these d'Etat, U. S. T. L., Montpellier, France.

Burgess, R., S. P. Kelley, I. Parsons, F. D. L. Walker and R. H. Worden (1992), 40Ar/39Ar analysis of perthite microtextures and fluid inclusions in alkali feldspars from the Klokken syenite, south Greenland, Earth Planet. Sci. Lett, 109, 147-167.

Cheng, J., and G. Xu (1987), Geologic map of the Ritu region with report, pp. 598, Tibetan Bureau of Geological and Mineral Resources, Lhasa.

Chevalier, M. -L., F. J. Ryerson, P. Tapponnier, R. C. Finkel, J. Van Der Woerd, Haibing Li, and Qing Liu (2005), Slip-rate measurements on the Karakorum fault may imply secular variations in fault motion, Science, 307, 411-414.

Clemens, J. D. (2003), S-type granitic magmas--petrogenetic issues, models and evidence, Earth-Science Reviews, 61, 1-18.

Dalrymple, G. B. and M. A. Lanphere (1974), (super 40) Ar/ (super 39) Ar age spectra of some undisturbed terrestrial samples, Geochim. Cosmochim. Acta 38 (5), 715-738.

Davis A. M., J. C. Aitchison, Badengzhu, Luo Hui (2004), conglomerates record the tectonic evolution of the Yarlung-Tsangpo suture zone in southern Tibet, Geol. Soc. London, Spec. Pub., 226, 235-246.

Dunlap W. J., R. F.Weinberg, and M. P. Searle (1998), Karakoram fault zone rocks cool in two phases, Journal of the Geological Society of London 155 Part 6, 903-912.

Eisbacher, G. H. (1970), Deformation mechanics of mylonitic rocks and fractured granites in Cobequid Mountains, Nova Scotia, Can. Bull. Geol. Soc. Am., 81, 2009-2020. 
Farley, K. A. (2000), Helium diffusion from apatite: general behavior as illustrated by Durango fluorapatite, J. Geophys. Res., 105, (B2), 2903-2914.

Farley, K. A. (2002), (U-Th)/He Dating: Techniques, Calibrations, and Applications, Noble gases in geochemistry and cosmochemistry, Rev. Min. Geochem., (47), 819-843.

Farley, K. A., R. A. Wolf, and L. T. Silver (1996), The effects of long alpha-stopping distances on (U-Th)/He ages, Geochim. Cosmochim. Acta, 60 (21), 4223-4229.

Galbraith, R. F. (1981), On statistical models for fission track counts, Mathematical Geology, 13, 471-478.

Gansser, A. (1964), Geology of the Himalayas, Wiley, New York, 289 pp.

Gapais, D. (1989a), Les Orthogneiss : Structures, mécanismes de déformation et analyse cinématique, Mem. Doc. CAESS, 28, 1-366.

Gapais, D. (1989b), Shear structures within deformed granites: mechanical and thermal indications, Geology, 17, 1144-1147.

Gardien, V., A. B. Thompson, D. Grujic, and P. Ulmer (1995), Experimental melting of biotite + plagioclase + quartz \pm muscovite assemblages and implications for crustal melting, J. Geophys. Res., 100 (B8), 15,581-15,591.

Gates, A. E., and L. Glover (1989), Alleghanian tectono-thermal evolution of the dextral transcurrent hylas zone, Virginia Piedmont, USA, J. Struct. Geol., 11, 407-419.

Gaudemer, Y., P. Tapponnier, and D.L. Turcotte (1989), River offsets across active strikeslip faults, Ann. Tect., 3, 55-76.

Gleadow, A. J. W., I. R. Duddy, P.F. Green, and J.F. Lovering, (1986), Confined fission track lengths in apatite: a diagnostic tool for thermal history analysis, Contrib. Mineral. Petrol., 94, 405-415.

Gower, J. W., and C. Simpson (1992), Phase boundary mobility in naturally deformed, highgrade quartzofeldspathic rocks: evidence for diffusional creep, J. Struct. Geol., 14 (3), 301-313.

Green, P. F. (1981), A new look at statistics in fission-track dating, Nuclear Tracks, 5, 77-86.

Guillopé, M., and J.-P. Poirier (1979), Dynamic recrystallisation during creep of singlecrystalline halite: an experimental study, J. Geophys. Res., 84, 5557-5567.

Hames, W. E., and S. A. Bowring (1994), An empirical evaluation of the argon diffusion geometry in muscovite, Earth Planet. Sci. Lett., 124, 161-169.

Harrison, T. M., I. Duncan, and I. McDougall (1985), Diffusion of ${ }^{40} \mathrm{Ar}$ in biotite: temperature, pressure and compositional effect, Geochim. Cosmochim. Acta, 49, 2461-2468.

Harrison, T.M., M.T. Heizler, O.M. Lovera (1991), ${ }^{40} \mathrm{Ar} /{ }^{39} \mathrm{Ar}$ results for alkali feldspar containing diffusion domains with differing activation energy, Geochim. Cosmochim. Acta, 55, 1435-1448.

Harrison, T.M., M.T. Heizler, O.M. Lovera, Wenji Chen, and M.A. Grove (1994), Chlorine disinfectant for excess argon released from K-feldspar during step heating, Earth Planet. Sci. Lett., 123, 95-104.

Harrison T. M., Leloup P. H., Ryerson F. J., Tapponnier P., Lacassin R., and Wenji C. (1996), Diachronous initiation of Transtension along the Ailao Shan-Red River Shear zone, Yunnan and Vietnam. In The Tectonics of Asia (ed. T. M. Harrison and Y. An), pp. pp. 208-226. Cambridge University Press.

Hirth, G., and J. Tullis (1992), Dislocation creep regimes in quartz aggregates, J. Struct. Geol., 14, 145-159. 
House, M. A., K. A. Farley, and D. Stockli (2000), Helium chronometry of apatite and titanite using Nd-YAG laser heating, Earth Planet. Sci. Lett., 183 (3-4), 365-368.

House, M. A., B.P. Wernicke, B. P. and K.A. Farley (2001), Paleo-geomorphology of the Sierra Nevada, California, from (U-Th)/He ages in apatite, Am. J. Sci.,301, 77102.

Hurford, A. J., and Green, P. F., (1983), The zeta age calibration of fission-track dating. Chem. Geol., 41, 285-317.

Jensen, L. N., and J. Starkey (1985), Plagioclase microfabrics in a ductile shear zone from the Jotun Nappe, Norway, J. Struct. Geol., 7 (5), 527-539.

Ji, S., and D. Mainprice (1990), Recrystallization and fabric development in plagioclase, $J$. Geol., 98, 65-79.

Jiao, S., Y. Zhang, S. Yi, C. Ai, Y. Zhao, Y. Li, H. Wang, J. Xu, J. Hu, T. Guo (1988), Geological map of Qinhai-Xizang Plateau and adjacent areas, Geological Publishing House, Beijing.

Kapp, P., M. A. Murphy, A. Yin, and T. M. Harrison (2003), Mesozoic and Cenozoic tectonic evolution of the Shiquanhe area of western Tibet Tectonics, 22 (4), Art. no. 1029.

Ketcham, R. A., R. A. Donelick, and W. D. Carlson (1999), Variability of apatite fissiontrack annealing kinetics: III. Extrapolation to geologic timescales, American Mineralogist, 84, 1235-1255.

Kirschner, L., M. A. Cosca, H. Masson, and J. C. Hunziker (1996), Staircase 40Ar/39Ar spectra of fine-grained white mica: timing and duration of deformation and empirical constraints on argon diffusion, Geology, 24 (8), 747-750.

Kretz, R. (1983), Symbols for rock-forming minerals, Am. Mineral., 68, 227-279.

Lacassin, R., F. Valli, N. Arnaud, P. H. Leloup, J. -L. Paquette, Haibing Li, P. Tapponnier, M. -L. Chevalier, S. Guillot, G. Mahéo, and Zhiqin Xu (2004), Large-scale geometry, offset and kinematic evolution of the Karakorum fault, Tibet, Earth Planet. Sci. Lett., 219, 255-269.

Leloup, P. H., R. Lacassin, P. Tapponnier, Zhong Dalai, Liu Xiaohan, Zhang Lianshang, Ji Shaocheng and Phan Trong Trinh (1995), The Ailao Shan-Red River shear zone (Yunnan, China), Tertiary transform boundary of Indochina, Tectonophysics, 251, 384.

Leloup P. H., Y. Ricard, J. Battaglia, and R. Lacassin (1999), Shear heating in continental strike-slip shear zones : model and field examples. Geophys. J. Int. 136, 19-40.

Leloup, P. H., N. Arnaud, R. Lacassin, J. R. Kienast T. M. Harrison, P. T. Trinh, A. Replumaz, and P. Tapponnier (2001), New constraints on the structure, thermochronology and timing of the Ailao Shan - Red River shear zone, J. Geophys. Res., 106(B4), 6657-6671.

Liu, Qing (1993), Paléoclimats et contraintes chronologiques sur les mouvements récents dans l'ouest du Tibet: failles du Karakorum et de Longmu Co - Gozha Co, lacs en pull-apart de Longmu Co et de Sumxi Co, Paris 7.

Lovera, O.M., F.M. Richter and T.M. Harrison (1989), $\mathrm{The}{ }^{40} \mathrm{Ar} /{ }^{39} \mathrm{Ar}$ thermochronometry for slowly cooled samples having a distribution of diffusion domain sizes, J. Geophys. Res., 94 (12), 17917-17935.

Lovera, O. M., F. M. Richter and T. M. Harrison (1991), Diffusion domains determined by ${ }^{39}$ Ar released during step heating, J. Geophys. Res., 96, 2057-2069. 
Lovera O. M., M. Grove, T. M. Harrison, and K. I. Mahon (1997), Systematic analysis of Kfeldspar $40 \mathrm{Ar} / 39 \mathrm{Ar}$ step heating results: I. Significance of activation energy determinations. Geochim. Cosmochim. Acta 61,15, 3171-3192.

Mahéo, G., A. Pêcher, S. Guillot, Y. Rolland, and C. Delacourt (2004). Exhumation of Neogene gneiss dome between two oblique crustal boundaries in south Karakorum (NW, Himalaya, Pakistan). In: " Gneiss Domes in Orogeny", Whitney, D.L., Teyssier, C., and Siddoway, C.S., editors, Geol. Soc. Am. Spec. Pap., 380, 141-154.

Matte, P., P. Tapponnier, N. Arnaud, L. Bourjot, J. P. Avouac, P. Vidal, Liu Qing, Pan Yusheng and Wang Yi (1996), Tectonics of Western Tibet, between the Tarim and the Indus, Earth Planet. Sci. Lett., 142, 311-330.

Miller, C., R. Schuster, U. Klötzli, W. Frank, and B. Grasemann (2000), Late CretaceousTertiary magmatic and tectonic events in the Transhimalaya batholith (Kailas area, SW Tibet), Schweizerische Mineralogische und Petrographische Mitteilungen, 80, 120.

Molnar, P., and G. A. Houseman (2004), The effects of buoyant crust on the gravitational instability of thickened mantle lithosphere at zones of intracontinental convergence, Geophys. J. Int., 158, 1134-1150.

Murphy, M. A., A. Yin, P. Kapp, T. M. Harrison, Lin Ding, and Jinghui Guo (2000), Southward propagation of the Karakoram fault system, Southwest Tibet; timing and magnitude of slip, Geology (Boulder), 28 (5), 451-454.

Murphy, M. A., A. Yin, P. Kapp, T. M. Harrison, C. E. Manning, F. J. Ryerson, Lin Ding, and Jinghui Guo (2002), Structural evolution of the Gurla Mandhata detachment system, Southwest Tibet; implications for the eastward extent of the Karakoram fault system, Geol. Soc. Am. Bull., 114 (4), 428-447.

Olesen, N. O. (1987), Plagioclase fabric development in a high-grade shear zone, Jotunheimen, Norway, Tectonophysics, 142, 291-308.

Olsen, T. S., and D. L. Kohlstedt (1985), Natural deformation and recrystallisation of some intermediate plagioclase feldspars, Tectonophysics, 111, 107-131.

Parrish, R. R., and R. Tirrul (1989), U-Pb age of the Baltoro granite, northwest Himalaya, and implications for monazite U-Pb systematics, Geology, 17, 1076-1079.

Passchier, C. W. (1982), Mylonitic deformation in the Saint Barthélemy Massif, French Pyrenees, with emphasis on the genetic relationship between ultramylonite and pseudotachylyte, GUA Pap. Geol. Ser. 1, 16, 1-173.

Passchier, C. W., and R. A. J. Trouw (1996), Microtectonics, 289 pp., Springer-Verlag, Berlin.

Phillips, R. J., R. R. Parrish, M. P. Searle (2004), Age constraints on ductile deformation and long-term slip rates along the Karakoram fault zone, Ladakh, Earth Planet. Sci. Lett., 226, 305-319.

Ratschbacher, L., Frisch, W., Liu, G. and C. C. Cheng (1994), Distributed deformation in Southern and Western Tibet as result of the India-Asia collision. J. Geophys. Res., 99, B10, 19917-19945.

Roddick, J. C. (1978), The application of isochron diagrams in (super 40) Ar - (super 39) Ar dating, a discussion, Earth Planet. Sci. Lett., 41 (2), 233-244.

Roddick, J.C., R.A. Cliff, and D.C. Rex (1980), The evolution of excess argon in alpine biotites, a 40Ar/39Ar analysis, Earth Planet. Sci. Lett., 48, 185-208.

Rolland, Y., A. Pêcher, G. Mahéo, I. M. Villa; Syn-kinematic emplacement of the Pangong metamorphic and magmatic complex along the Karakorum Fault (N Ladakh); J. 
Asian Earth Sciences, In press.

Rolland, Y. (2000), De la convergence intra-océanique à l'évolution post-collisionnelle: exemple de la convergence indo-asiatique en Himalaya du NW du Crétacé à nos jours. ph D thesis Grenoble Univ., France, 267p.

Rolland, Y. (2002), From intra-oceanic convergence to post-collisional evolution; example of the India-Asia convergence in NW Himalaya, from Cretaceous to present, Journal of the Virtual Explorer, 8, 185-208.

Rolland, Y., and A. Pêcher (2001), The Pangong granulites of the Karakoram Fault (Western Tibet): vertical extrusion within a lithosphere-scale fault ?, C. R. Acad. Sci., 332, 363370.

Schmitz, M. D., and S. A. Bowring, (2001), U-Pb zircon and titanite systematics of the Fish Canyon Tuff: an assessment of high-precision U-Pb geochronology and its application to young volcanic rocks, Geochim. Cosmochim. Acta, 65 (15), 2571-2587.

Schmitz, M. D., S. A. Bowring, K. R. Ludwig, and P. R. Renne (2003), Comment on "Precise K-Ar, 40Ar-39Ar, Rb-Sr and U-Pb mineral ages from the 27.5 Ma Fish Canyon Tuff reference standard" by M.A. Lanphere and H. Baadsgaard, Chem. Geol., 199 (3-4), 277-280.

Schwab, M., L. Ratschbacher, W. Siebel, M. McWilliams, V. Minaev, V. Lutkov, F. Chen, K. Stanek, B. Nelson, W. Frisch, and J. L. Wooden (2004), Assembly of the Pamirs: Age and origin of magmatic belts from the southern Tien Shan to the southern Pamirs and their relation to Tibet, Tectonics, 23, TC4002, doi:10.1029/2003TC001583.

Searle, M. P., (1996), Geological evidence against large-scale pre-Holocene offsets along the Karakorum fault: implications for the limited estrusion of the tibetan plateau, Tectonics, 15 (1),

Searle, M. P., R. F. Weinberg, and W. J. Dunlap (1998), Transpressional tectonics along the Karakoram fault zone, northern Ladakh: constraints on Tibetan extrusion, in Continental Transpressional and Transtensional Tectonics, edited by R. E. Holdsworth, R. A. Strachan, and J. F. Dewey, Geol. Soc., London, Spec. Pub., 135, 307-326.

Seydoux-Guillaume, A.-M., et al. (2002), Experimental resetting of the U-Th-Pb systems in monazite, in Chemical Geology, edited by F. Poitrasson, et al., pp. 165-181, Elsevier, Amsterdam.

Simpson, C., and R. P. Wintsch (1989), Evidence for deformation-induced K-feldspar replacement by myemekite, J. Metam. Geol., 7, 261-275.

Sobel, E. R., and M. R. Strecker (2003), Uplift, exhumation, and precipitation: Tectonic and climatic control of Late Cenozoic landscape evolution in the northern Sierras Pampeanas, Argentina, Basin Research, 15, doi: 10.1046/j.1365-2117.2003.00214.x.

Stesky, R. M. (1978), Mechanisms of high temperature frictional sliding in Westerly granite, Can. J. Earth Sci., 15, 361-375.

Stesky, R. M., W. F. Brace, D. K. Riley, and P. Y. F. Robin (1974), Friction in faulted rock at high temperature and pressure, Tectonophysics, 23, 177-203.

Tapponnier, P., Zhiqin Xu, F. Roger, B. Meyer, N. Arnaud, G. Wittlinger, and Jingsui Yang (2001), Oblique stepwise rise and growth of the Tibet Plateau, Science, 294 (5547), 1671-1677.

Tsurumi, J., H. Hosonuma, and K. Kanagawa (2003), Strain localization due to a positive feedback of deformation and myrmekite-forming reaction in granite and aplite mylonites along the Hatagawa Shear Zone of NE Japan, J. Struct. Geol., 25, 557-574. 
Tullis, Y. E., and R. A. Yund (1987), Transition from cataclastic flow to dislocation creep of feldspar: mechanisms and microstructures, Geology, 15, 606-609.

Tullis, T.E., and R.A. Yund (1991), Diffusion creep in feldspar aggregates: experimental evidence, J. Struct. Geol., 13, 987-1000.

Valli, F. (2005), Décrochements lithosphériques dans l'Ouest du plateau du Tibet : Géométrie, âge, décalages cumulés et vitesse de glissement long-terme sur la Faille du Karakorum, phd thesis, IPGP.

Valli, F., JL. Paquette, Haibing Li, P.H. Leloup, N. Arnaud, S. Guillot, R. Lacassin, P. Tapponnier, Dunyi Liu, E. Deloule, Zhiqin Xu (in prep.), Ductile deformation and magmatism along the Karakorum fault, Western Tibet: U-Th-Pb geochronological constraints, submitted to J. Geophys. Res.

White, S. (1975), Tectonic deformation and recrystallisation of oligoclase, Contrib. Mineral. Petrol., 50, 287-304.

Weinberg R. F. and W. J. Dunlap (2000), Growth and deformation of the Ladakh Batholith, Northwest Himalayas; implications for timing of continental collision and origin of calc-alkaline batholiths, Journal of Geology 108(3), 303-320.

White, J. C., and C. K. Mawer (1986), Extreme ductility of feldspars from a mylonite, Parry Sound, Canada, J. Struct. Geol., 8, 133-143.

Yin, A, T.M. Harrison, M.A. Murphy, M. Grove, S. Nie, F.J. Ryerson, X. Wang, and Z. Chen (1999), Tertiary deformation history of southeastern and southwestern Tibet during the Indo-Asian collision, Geol. Soc. Am. Bull., 111 (11), 1644-1664.

York, D. (1969), Least squares fitting of a straight line with correlated errors, Earth Planet. Sci. Lett., 5, 320-324.

Zhang, J., L. Ding, D. Zhong, and Y. Zhou (2000), Orogen-parallel extension in Himalaya: Is it indicator of collapse or the product in process of compressive uplift?, Chin. Sci. Bull., 45 (2). 


\section{Figure captions:}

Figure 1: Large-scale sketch map of KFZ and adjacent units. Inset shows location in the large-scale Asian active tectonic framework. Dark-gray tones outline the Indus-Zangbo, the Bangong-Nujiang/Rushan-Pshart suture zones, and the main continental blocks. Hatched tones correspond to Shiquanhe and Shyok suture zones. Faults are mapped from Brunel et al. [1994], Lacassin et al. [2004a], Ministry of Geology of USSR [1989], Tapponnier et al. [2001], and Weinberg and Dunlap [2000]. PU, Plutonic Unit; TSZ, Thanglasgo Shear Zone. Map is projected in UTM 44 using the ellipsoid WGS84.

Figure 2: Geological map of the double rhomb-shape Gar-Baer basin. Drawn from field observations, satellite image interpretation (Landsat 7, Spot 5, SRTM), and pre-existing maps [Armijo et al., 1989; Jiao et al., 1988; Kapp et al., 2003; Matte et al., 1996; Murphy et al., 2000]. Light shading outlines topography. Green lines show sections studied in the field (1 to 6 see Fig.4) and regional cross sections (A-A' and B-B' see Fig. 3b \& c). B: Baer, G: Gar, M: Menshi, S: Shiquanhe, T: Tsada, Z: Zhaxigang. Map is projected in UTM 44 using the ellipsoid WGS84.

Figure 3: Panoramic field photograph of the Ayilari range and cross-sections. Section locations and legend are on Figure 2. a: the Gar pull-apart basin and the north Ayilari range seen from the northeastern side of the basin (point of view location reported on Figure 2). The main active dextral / normal strand of the KF follows the foot of the topography evidenced by cumulative several hundreds meters high triangular facets. b: A-A' section across the north Ayilari range. c: B-B' section passing through the southern Ayilari range. Some units were not clearly seen and are postulated by question mark. Movements on the southern strand of the KFZ are postulated from satellite imagery, and large scale reconstruction as postulated in Lacassin et al. 2004.

Figure 4: Five geological sections on the northern side of the north Ayilari range, west of Shiquanhe (location on Figure 2). Samples quoted were dated with Ar-Ar, U-Th-He, fission 
tracks (this study), or U-Th-Pb techniques (shaded samples [Valli, 2005; Valli et al., submitted]).

Figure 5: Structural data from the North Ayilari range (lower hemisphere Schmidt diagrams). Great circles are foliation planes; dashed great circles represent $\mathrm{C}$ (shear) planes; and arrows show the direction of lineations with the arrow pointing towards the hanging wall motion. Extreme and average values of lineation stikes are indicated. Left and right columns correspond to greenschist and higher grade metamorphic facies, respectively.

Figure 6: Characteristics of deformation along the Karakorum shear zone. a: Steep foliation with an horizontal lineation made of stretched feldspar, quartz and mica in a leucocratic vein (section 2, Figure 2). The hammer is for scale. b: Steep foliation (S) transposed along the shear (C) planes in two-mica gneisses close to the frontal part of valley (section 3, Figure 2). The bag gives scale. c: dextrally sheared leucogranitoid seen from above (section 3, Figure 2). The compass is for scale. d: Two-mica gneiss exhibiting dextrally sheared sigmoidal feldspars (section 2, Figure 2). View from above.

Figure 7: Optical photomicrographs under cross-polarized light of feldspar microstructures. a: feldspar porphyroclast surrounded by a mantle of re-crystallized feldspars (arrows, sample C38). b: Well-developed myrmekite (Myr.) on a K-feldspar grain (K-fs) boundary (arrows, sample P32). c: bending of feldspar twin lamellae by dislocation glide (arrows, sample C29).

Figure 8: Optical photomicrographs under cross polarized light of quartz microstructures. a : relics of large old quartz grains with undulose extinction and elongate subgrains passing laterally into domains of small grains dynamically re-crystallized, probably by subgrain rotation re-crystallization (sample P32). b. Polycrystalline quartz with irregular grain boundaries formed in response to grain boundary migration re-crystallisation (sample P32).

Figure 9: Typical ${ }^{40} \mathrm{Ar} /{ }^{39} \mathrm{Ar}$ results from the north Ayilari range. Data are summarized in Table 3, 4, 5, and samples located on Figure 4. All other samples are shown in appendix. Left: conventional age spectra; double arrows represent age plateaus or pseudoplateaus (see 
text for explanation on the calculation and use of these terms). Right: Inverse isochrones for which each step is plotted with the corresponding error bars and step number. The regression line corresponds to the calculated age and ${ }^{40} \mathrm{Ar} /{ }^{39} \mathrm{Ar}_{\mathrm{i}}$. Step numbers in shaded boxes were not used for calculations. A: K-feldspar (sample L90). Superimposed curves represent synthetic age spectra resulting from thermal modeling at $2 \sigma$ confidence level. B: muscovite (sample C43). C: biotite (sample P56). Data from other samples, and $\mathrm{K} / \mathrm{Ca}, \mathrm{Cl} / \mathrm{K}$ plots are reported in the appendix: A (K-feldspar), B (muscovite), C (Biotite).

Figure 10: Time-temperature diagrams showing biotite, muscovite, and $\mathrm{K}$-feldspar ${ }^{40} \mathrm{Ar} /{ }^{39} \mathrm{Ar}$ age estimates, together with Fission Track (FT) and U-Th-He results on apatite. Ages are systematically $\sim 2-3$ Ma older in the northernmost valley (section 1) than in the other sections $(2,3,4,5)$. This implies a different time-temperature evolution between the northernmost section and the others, and consequently, data from this valley are plotted separately. A, B: northern most field section (1, location on Figure 2). C, D: other sections (2, 3, 4, 5, 6). Age uncertainties for the ${ }^{40} \mathrm{Ar} /{ }^{39} \mathrm{Ar}$ analysis include the entire range of isochron and plateau age estimates each quoted at the $2 \sigma$ confidence level; fission track and $\mathrm{U}-\mathrm{Th} / \mathrm{He}$ age estimates at $2 \sigma$ confidence level (see text for details). Continuous lines represent K-feldspar (A, C) and apatite cooling models (A, B, see text for details). Thick and fine curves are respectively the 95 and $65 \%$ confidence intervals of the best-fit cooling history (K-feldspar modelling has tested various solutions by a Monte Carlo algorithm to assess the variance of the resulting best fits). A, C: Note the inconsistency between most K-feldspar thermal models and mica age estimates. B, D: Preferred Time-Temperature history for the Ayilari range (see text for explanations). The cooling history is most likely bounded by the black-dashed lines, which were drawn by using a minimum of straight segments passing through all the data at $2 \sigma$ confidence level.

Figure 11: Cooling histories for the Ayilari and Pangong Ranges. Dashed lines represent the cooling histories. Mag, magmatic;;Zr, zircon; Mz, monazite. Ages are plotted with a $2 \sigma$ confidence level. A. North Ayilari range. $\mathrm{U}-\mathrm{Th}-\mathrm{Pb}$ data constraining the high temperature part of the diagram are from the work of Valli et al. [submitted], whereas the medium to low temperature evolution is documented in this study (Figure 10). The zircons and monazites 
are taken as constraining the crystallization of the syntectonic granites at ca $750-800^{\circ} \mathrm{C}$ [Clemens, 2003] The timing of onset of the KKF in the Ayilari range [Lacassin et al., 2004] and the onset of normal faulting (this study) are shown. B. Pangong Range. Data compiled from the literature and discussed in the text. Samples 129, 129A, 130, 135, 135A, 136, 212, 215, and 217 are from the work of [Dunlap et al., 1998]; the sample "Rolland" is from [Rolland, 2000; 2002; Rolland and Pecher, 2001]; the samples P1, P8, P11, P37 and P38 are from [Phillips et al., 2004]; and the samples 450, 022, and SC are from [Searle et al., 1998]. Data from $\mathrm{U} / \mathrm{Pb}$ analysis have been plotted accordingly to the published ages with uncertainties as discussed in the original papers, the temperature of crystallization being arbitrarily chosen between $650^{\circ} \mathrm{C}$ and $800^{\circ} \mathrm{C}$ as postulated in Valli et al. (submitted). Data from K-feldspar analysis were treated in a similar way to those from the present study: from the original data low temperature (LT) and high temperature (HT) pseudoplateaus were appreciated and are plotted with a range of closure temperature of $150-300^{\circ} \mathrm{C}$ and $300-400^{\circ} \mathrm{C}$ respectively (see text for discussion). Ages are plotted with a $2 \sigma$ confidence level.

Figure 12: Progressive offset along the Karakorum fault as can be postulated from the entrenchment of the Indus and Shyok rivers in the Ayilari range at $\sim 14 \mathrm{Ma}$ (see text for explanations). A. Arrows represent possible right-lateral apparent offset of the Indus river across the Karakorum fault. B. and C. show the corresponding hypothetical reconstructions at $\sim 14 \mathrm{Ma}$ if the Shiwuanhe basin is taken as the upstream of the Indus or Shyok river at that time. In the latter case the upstream of the Indus had to be somewhere south near Mt Kailas and could be at the origin of the deposits of the Kailas molasses. The Landsat 7 image is projected in UTM 44 using the ellipsoid WGS84. 


\section{Tables:}

Table 1: Mineralogical composition and grain size of the dated samples. Percentages are estimated from thin section with an optical microscope, crystal sizes are quoted in centimeter. Abbreviations are from Kretz [1983] (Tit: Titanite)

Table 2: Apatite (U-Th)/He ages. * Analytical uncertainty. Ages corrected for $\alpha$ ejection following method of Farley et al. [1996]. Analytical procedure after House et al. [2000]. r.: radius, 1.: length.

Table 3: K-feldspar ${ }^{40} \mathrm{Ar} /{ }^{39} \mathrm{Ar}$ results. LT, low furnace temperature $\left(400-700^{\circ} \mathrm{C}\right)$ age; HT, high furnace temperature $\left(1000-1400^{\circ} \mathrm{C}\right)$; SMA, Simple Mean Age. Errors are quoted at $2 \sigma$ confidence level.

Table 4: Muscovite ${ }^{40} \mathrm{Ar} /{ }^{39} \mathrm{Ar}$ results. Errors are quoted at $2 \sigma$ confidence level.

Table 5: Biotite ${ }^{40} \mathrm{Ar} /{ }^{39} \mathrm{Ar}$ results. Errors are quoted at $2 \sigma$ confidence level.

Table 6: Apatite fission track results. The pooled age is reported for all samples as they pass the $\mathrm{chi}^{2}$ test; error is one sigma, calculated using the zeta calibration method [Hurford and Green, 1983] with zeta of $369.6 \pm 7.6$ (E. Sobel, unpublished). No Xls* is the number of individual crystals dated. Rho-S, Rho-I, and Rho-D are the spontaneous, induced, and dosimetry track density measured (tracks $/ \mathrm{cm}^{2}$ ). NS and NI are the number of spontaneous and induced tracks counted. $\mathrm{P}(\mathrm{chi})^{2}(\%)$ is the chi-square probability [Galbraith, 1981; Green, 1981]. Sd and $\mathrm{n}$ are the standard deviation of the track lengths and number of measurements, respectively. Values greater than 5\% are considered to pass this test and represent a single population of ages. \#ND is the number of tracks counted in determining Rho-D; CN5 dosimetry glass used.

Appendix A: K-feldspar ${ }^{40} \mathrm{Ar} /{ }^{39} \mathrm{Ar}$ data from the north Ayilari range. Results are summarized in Table 3, and samples located on Figure 4. Left: conventional age spectra. 
Curves represent thermal modeling at $2 \sigma$ confidence level. Right: Inverse isochrones for which each step is plotted with the corresponding error bars and step number, the drawn regression line corresponds to the calculated age and ${ }^{40} \mathrm{Ar} /{ }^{39} \mathrm{Ar}_{\mathrm{i}}$. Step numbers in shaded boxes were not used for calculations. Bottom: $\mathrm{K} / \mathrm{Ca}$ and $\mathrm{Cl} / \mathrm{K}$ plots.

Appendix B: Muscovite ${ }^{40} \mathrm{Ar} /{ }^{39} \mathrm{Ar}$ data from the north Ayilari range. Results are summarized in Table 4, and samples located on Figure 4. Same caption as Appendix A.

Appendix C: Biotite ${ }^{40} \mathrm{Ar} /{ }^{39} \mathrm{Ar}$ data from the north Ayilari range. Results are summarized in Table 5, and samples located on Figure 4. Same caption as Appendix A. 


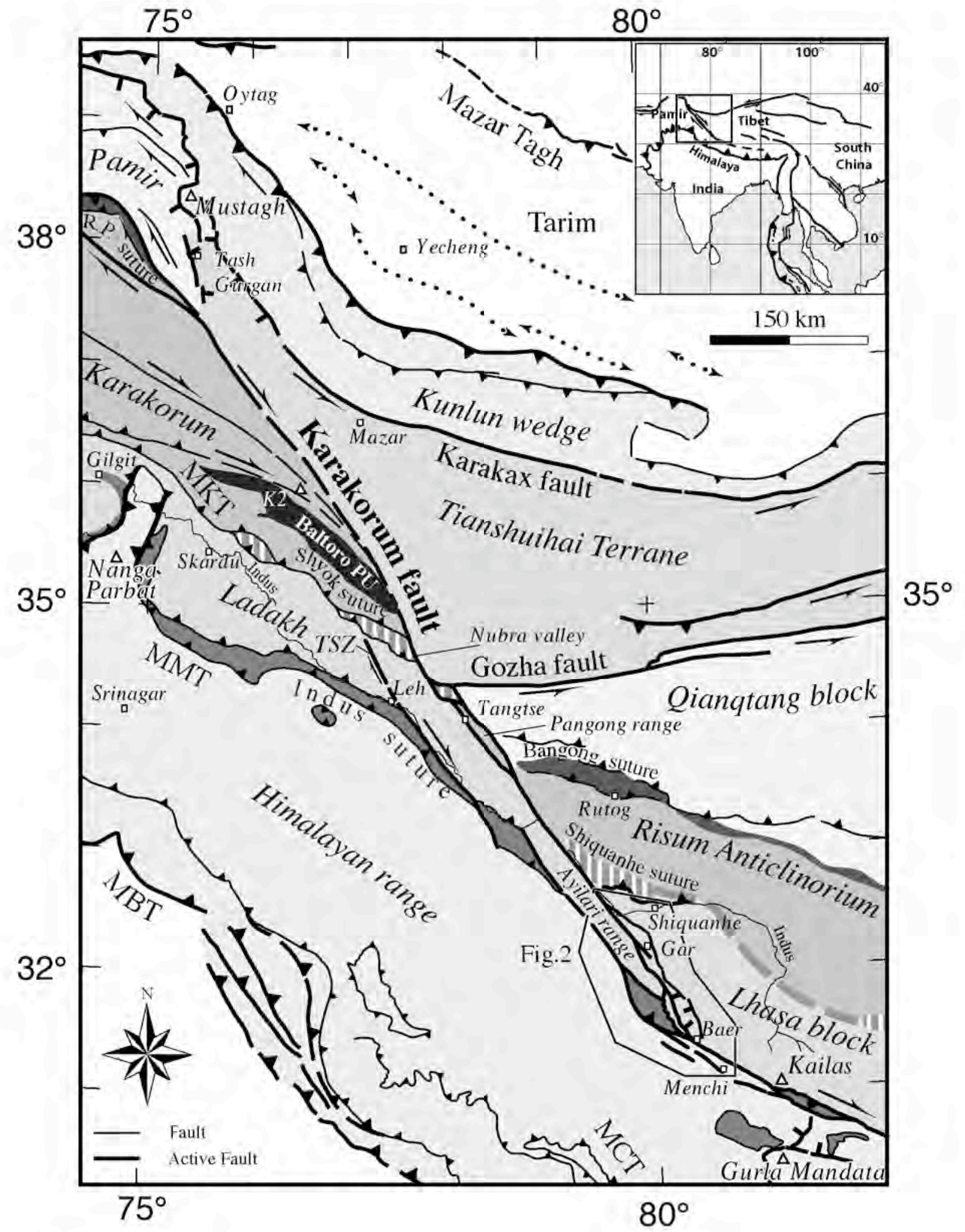

Figure 1 


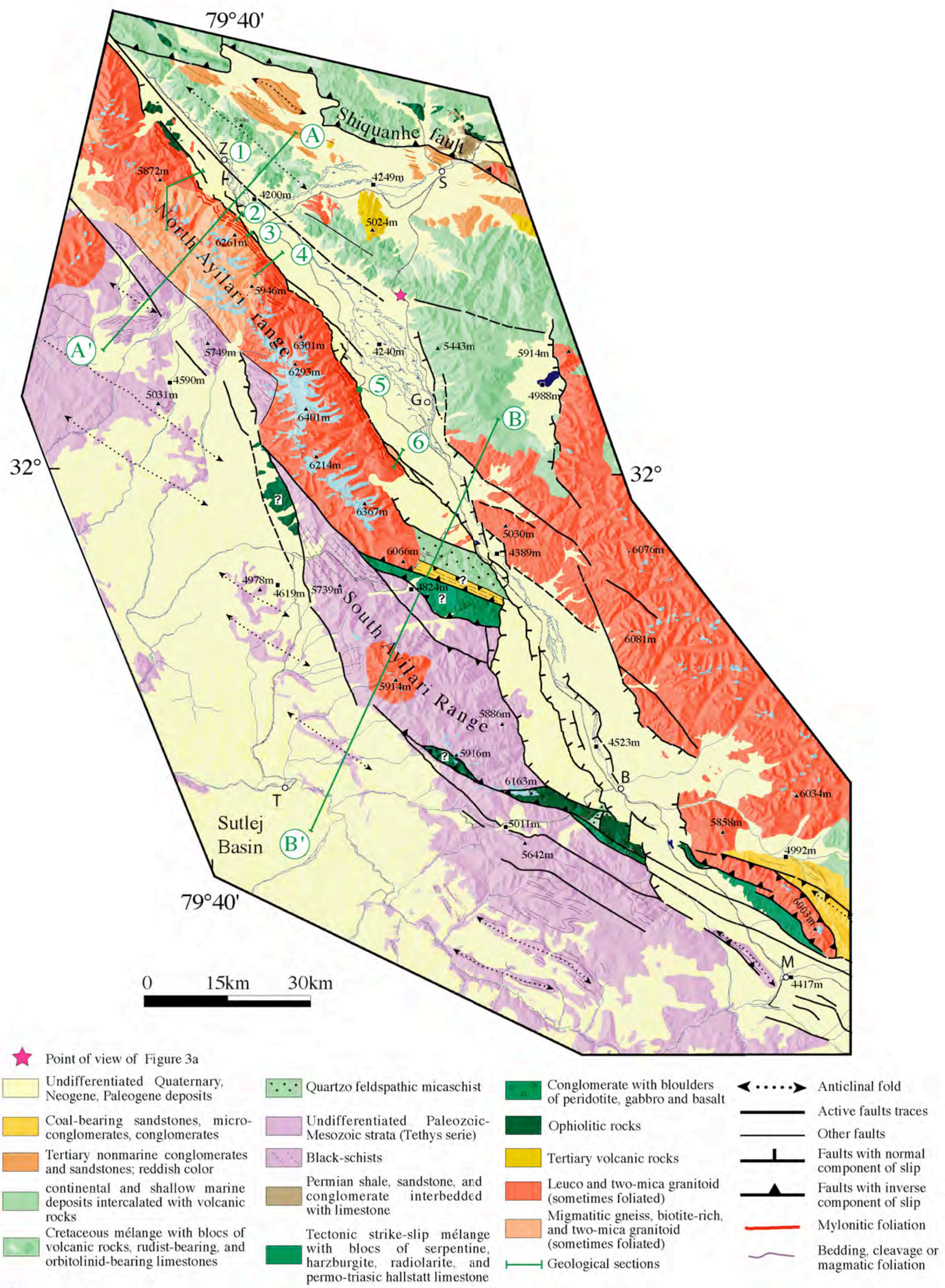

Figure 2 


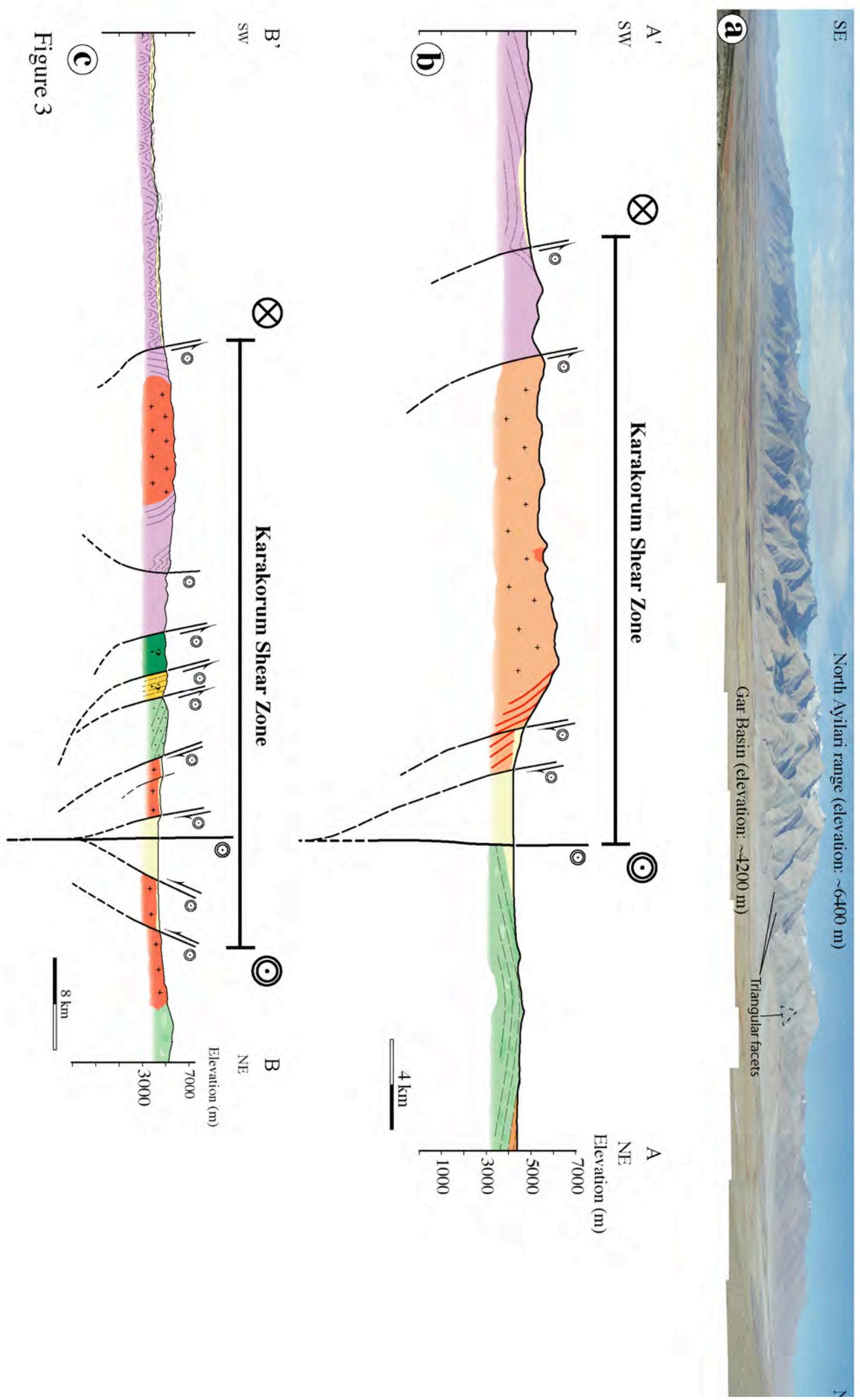



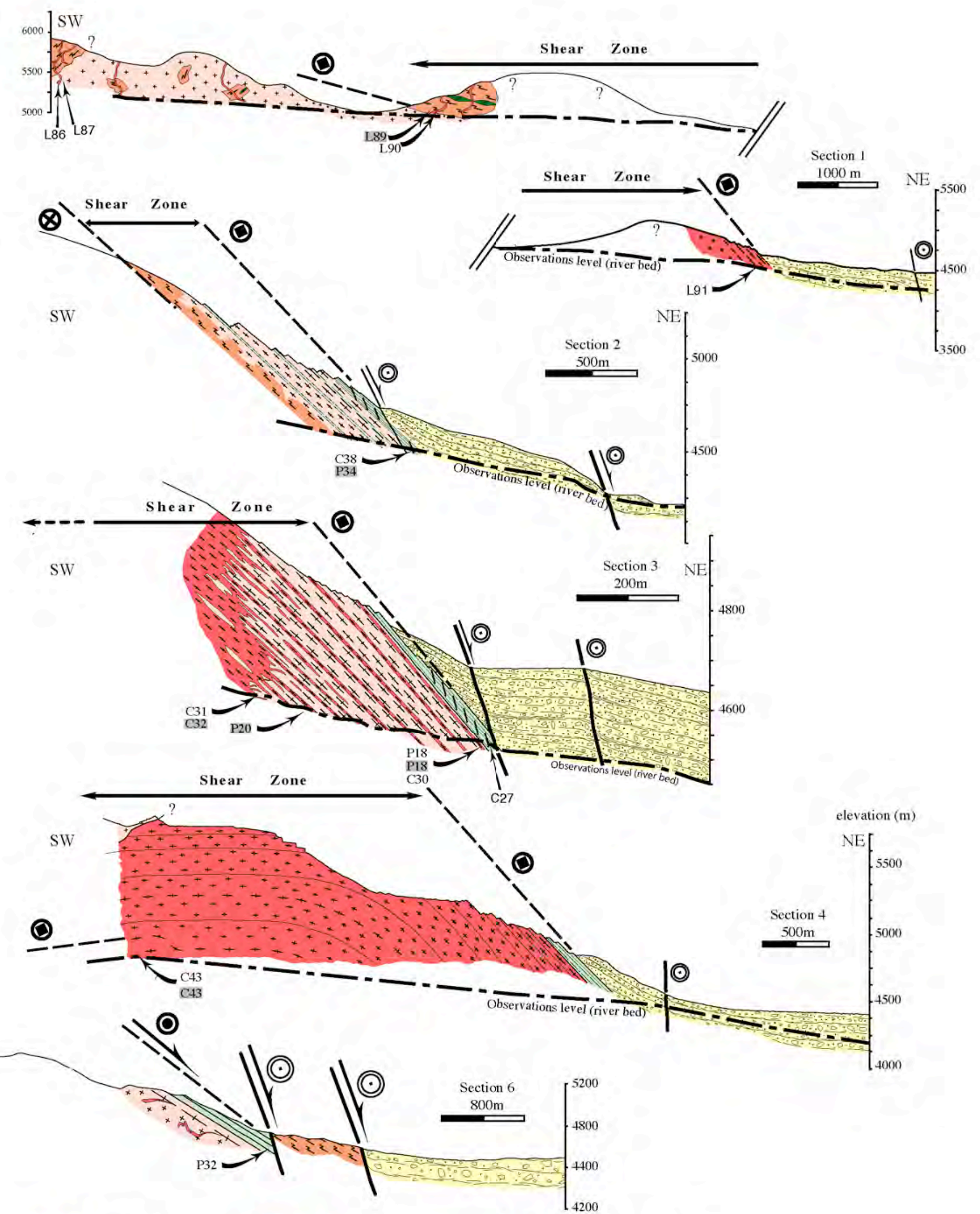

\footnotetext{
$\therefore$ Quaternary (moraines, fans)

III Greenschist Mylonite Leucoorthogneiss

$\begin{aligned} & \text { Biotite-rich and two- } \\ & \text { mica orthogneiss }\end{aligned}$
$+_{+}^{+} \begin{aligned} & \text { Biotite-rich and two- } \\ & \text { mica granitoid }\end{aligned}$ mica orthogneiss

\& Migmatitic gneisses

Amphibolite

++ Leucogranitoid
}

(-) Pre-Quaternary

deformation

(-) $\left\{\begin{array}{l}\text { Quaternary } \\ \text { deformation }\end{array}\right.$

1 Brittle-ductile normal shear zones

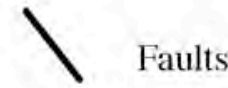

Figure 4 


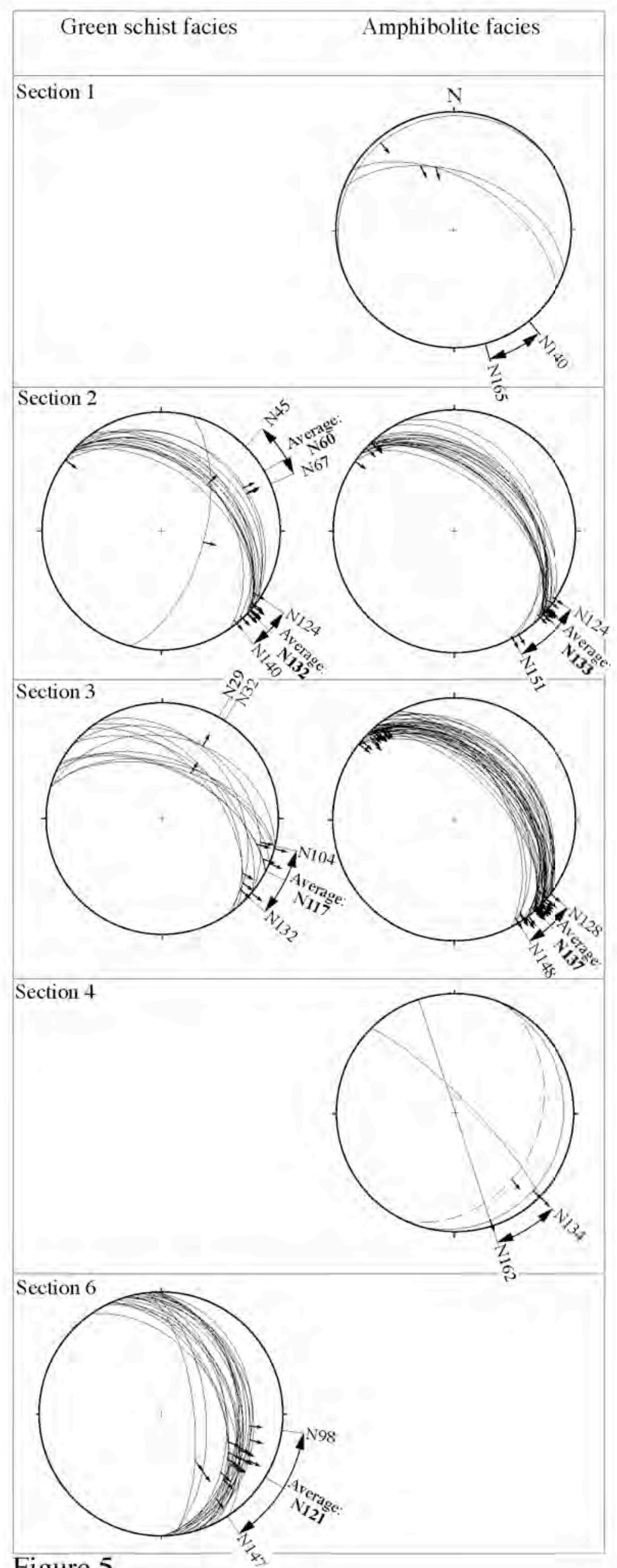

Figure 5 

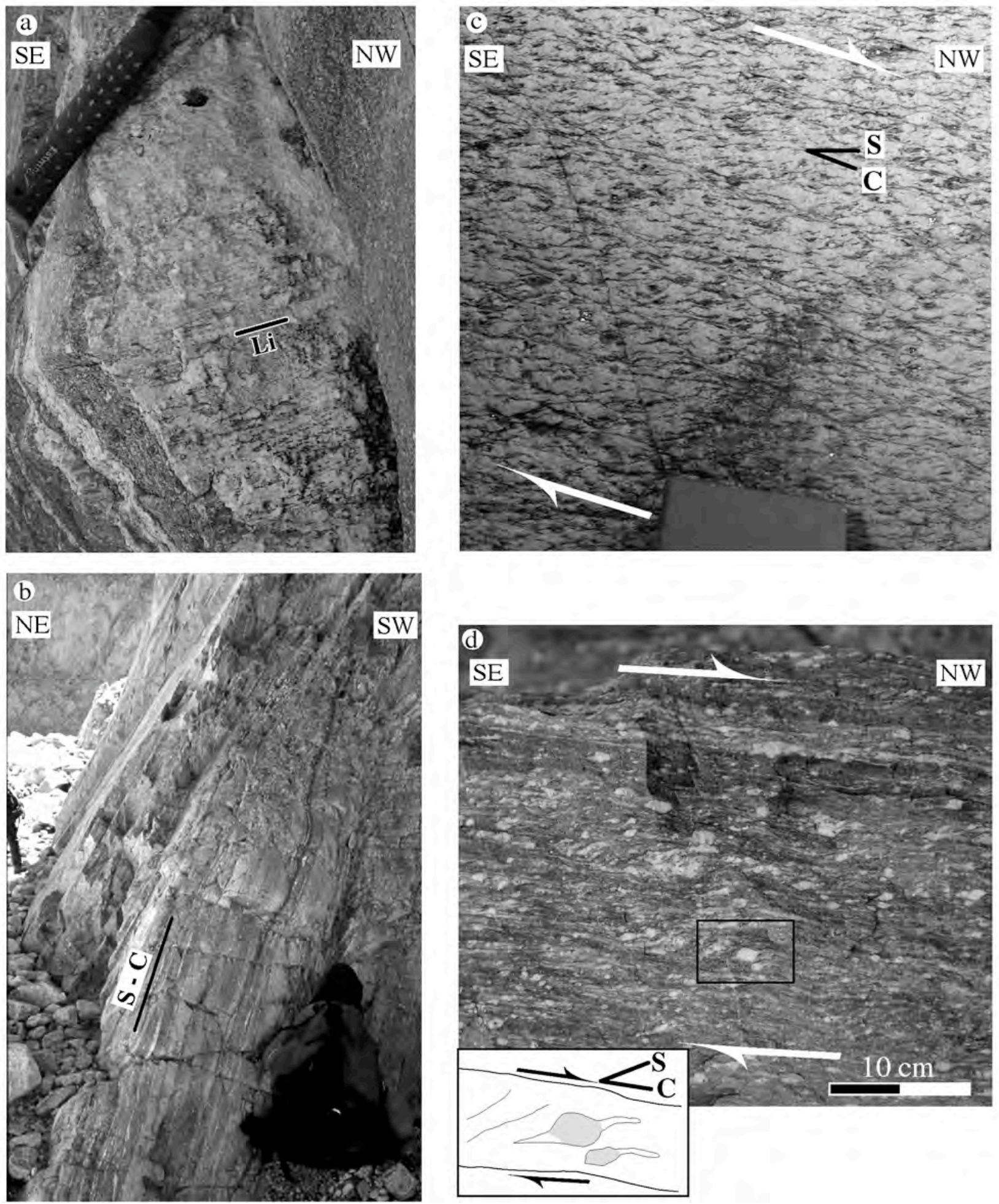

\section{Figure 6}



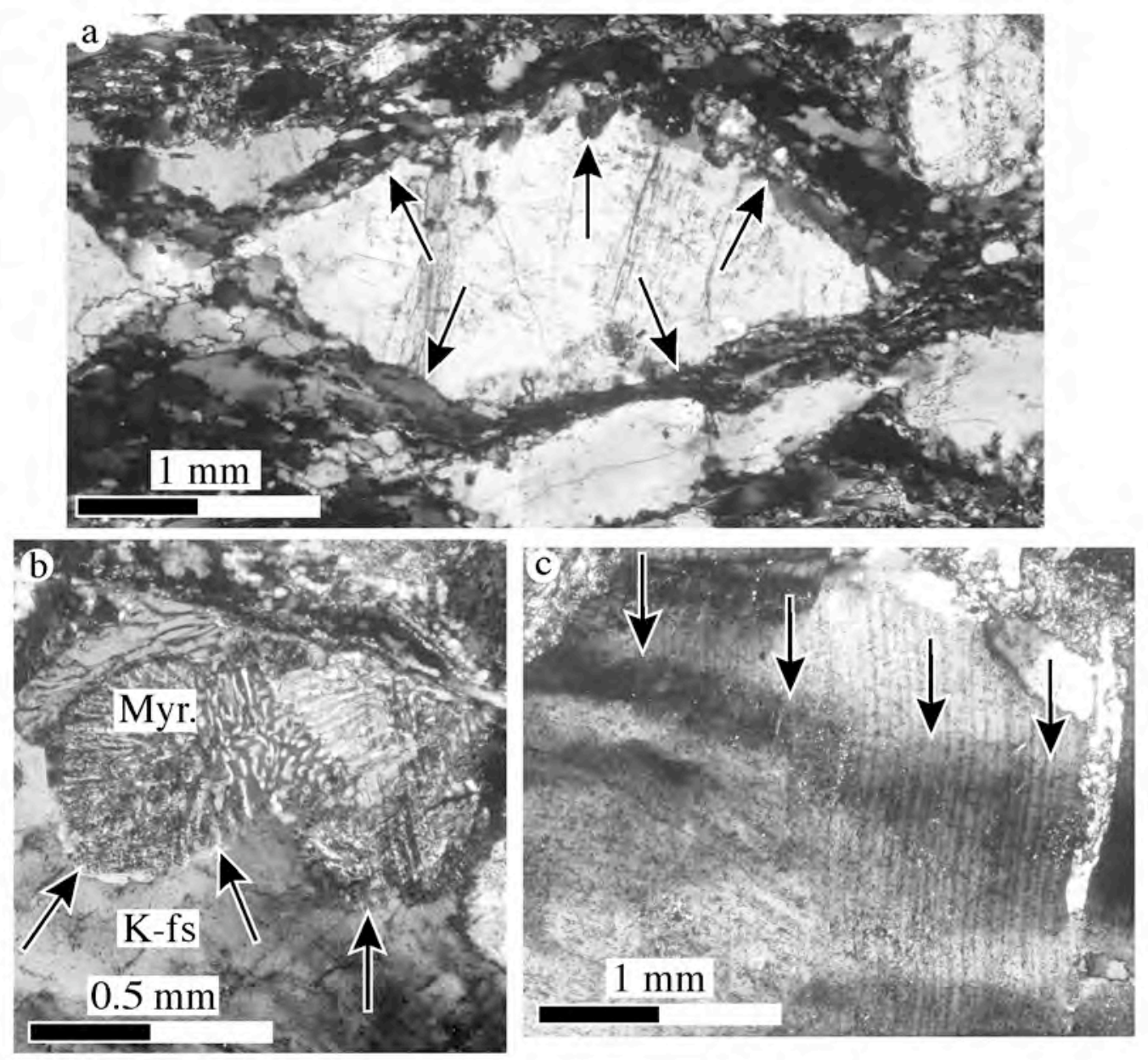

Figure 7 

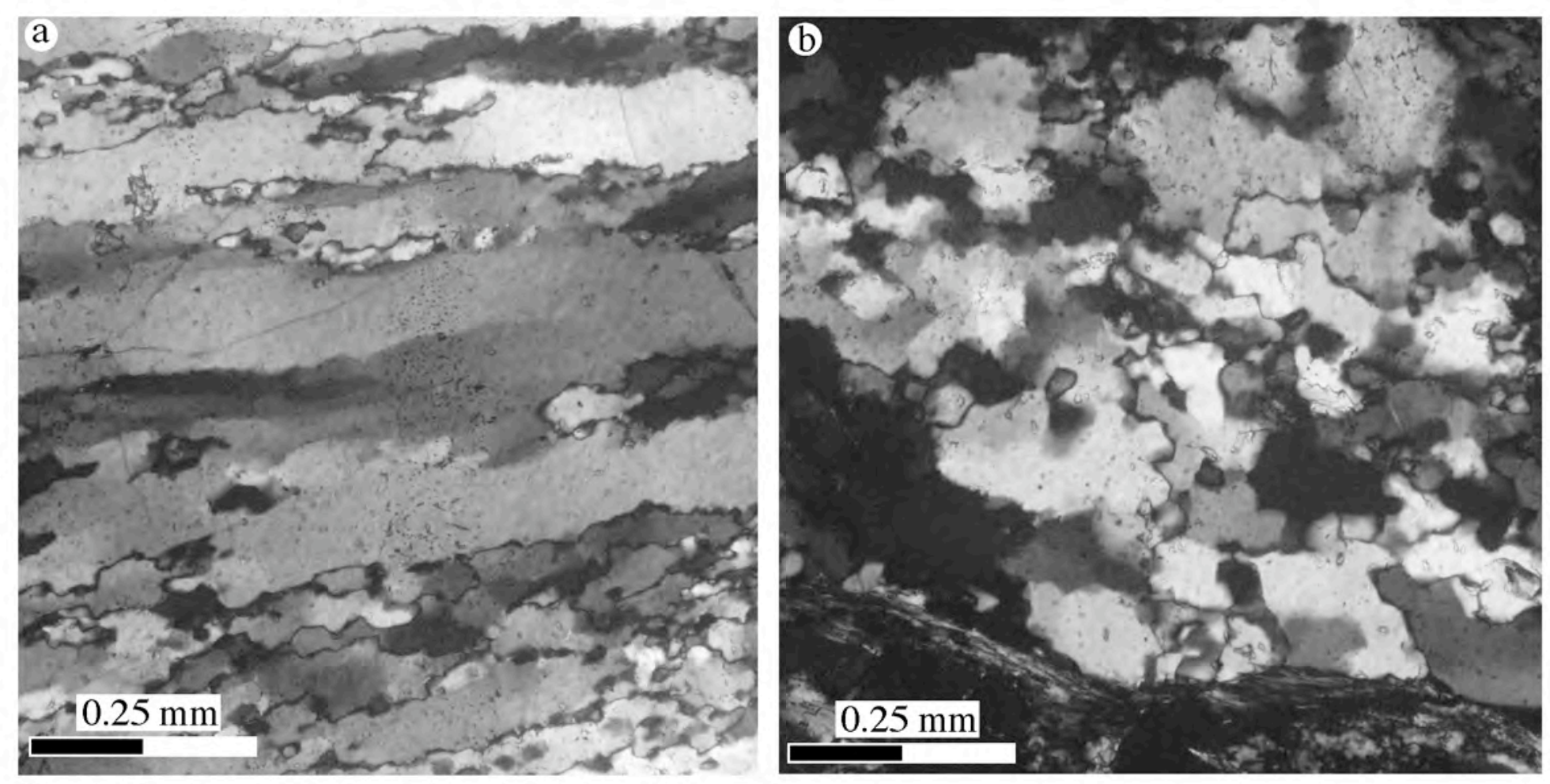

Figure 8 


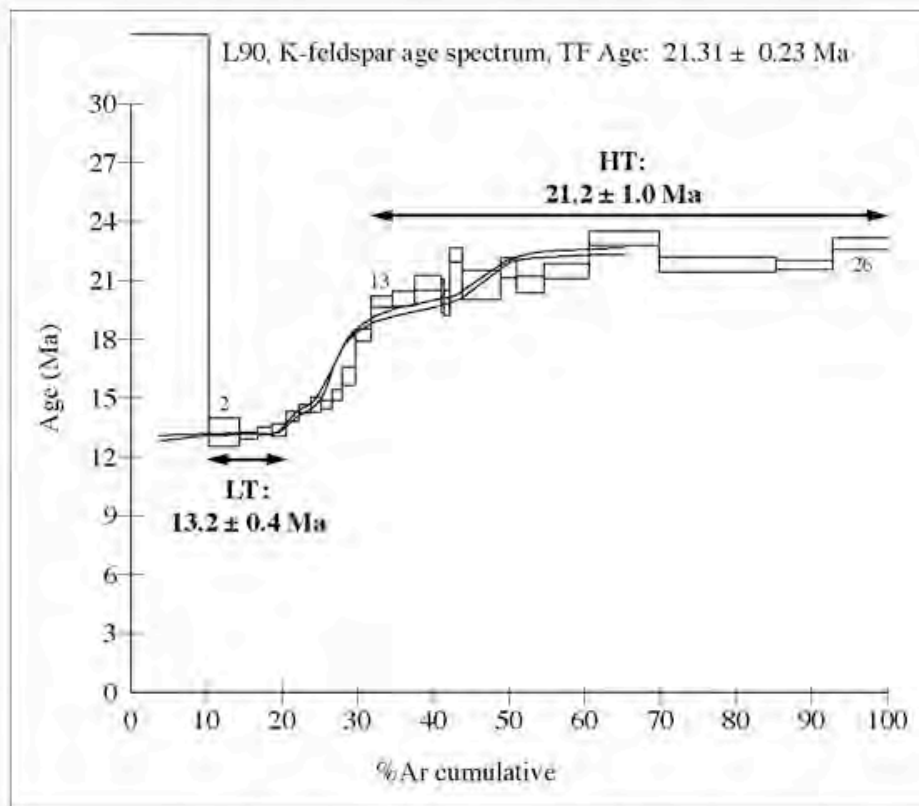

L90 K-feldspar inverse isochrou

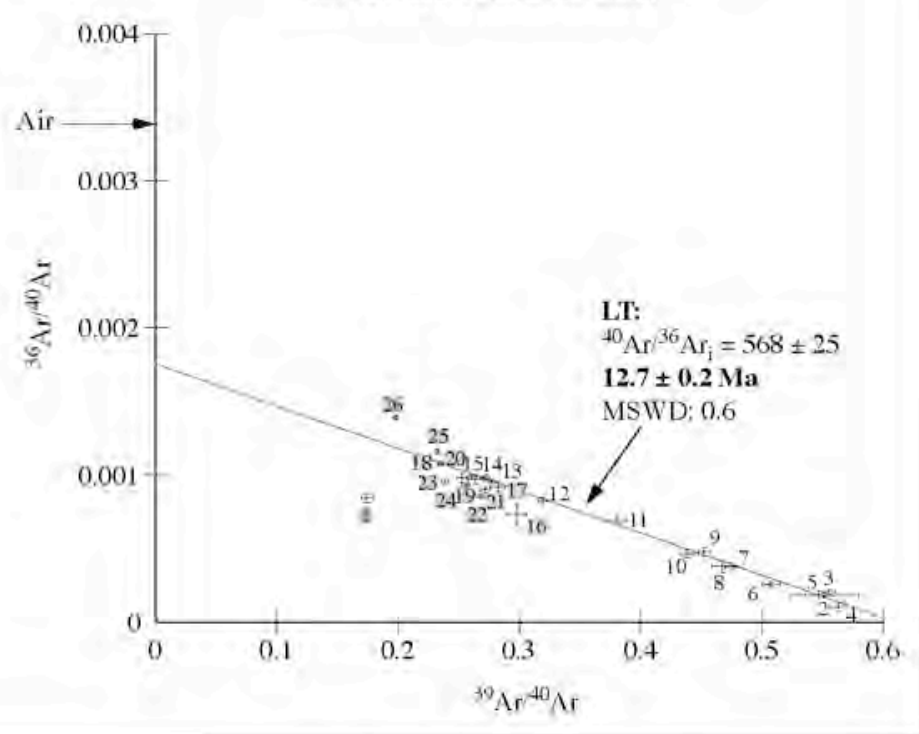

C43, Muscovite age spectrum. TF Age: $12.0 \pm 0.2 \mathrm{Ma}$

C43 Muscovite inverse isochron
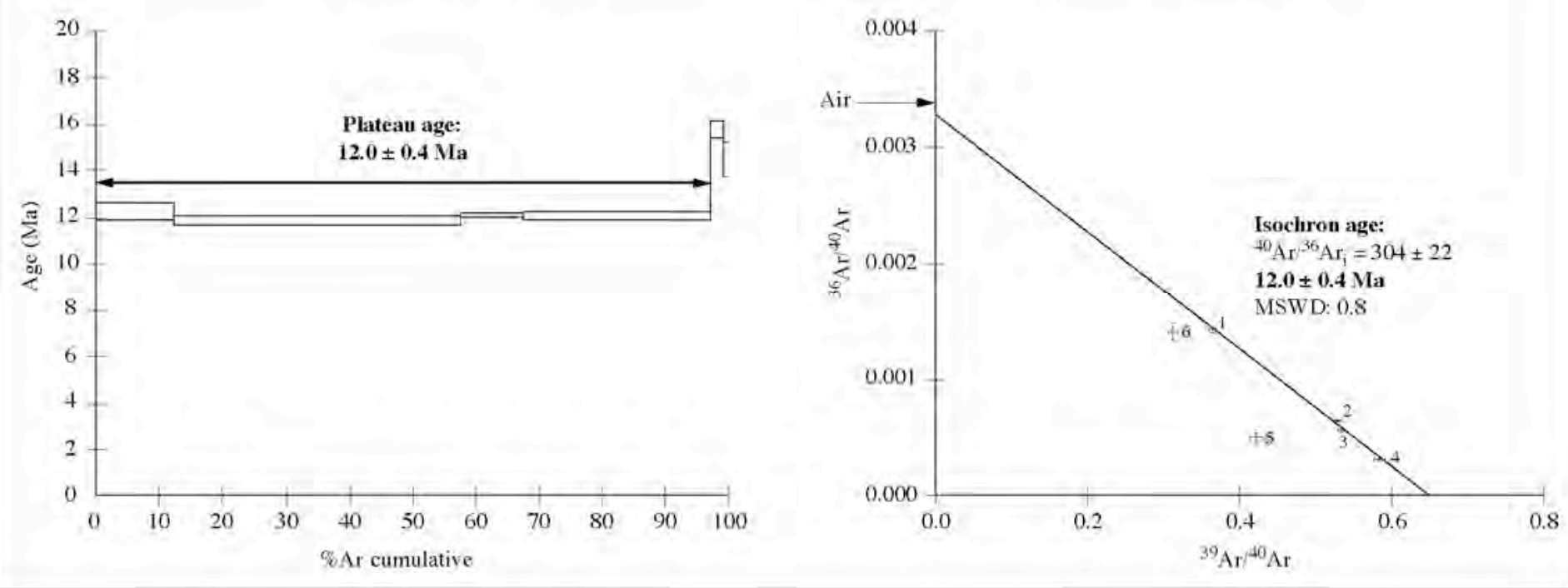

P56, Biotite age spectrum, TF Age: $11.9 \pm 0.2 \mathrm{Ma}$

P56 Biotite inverse isochron
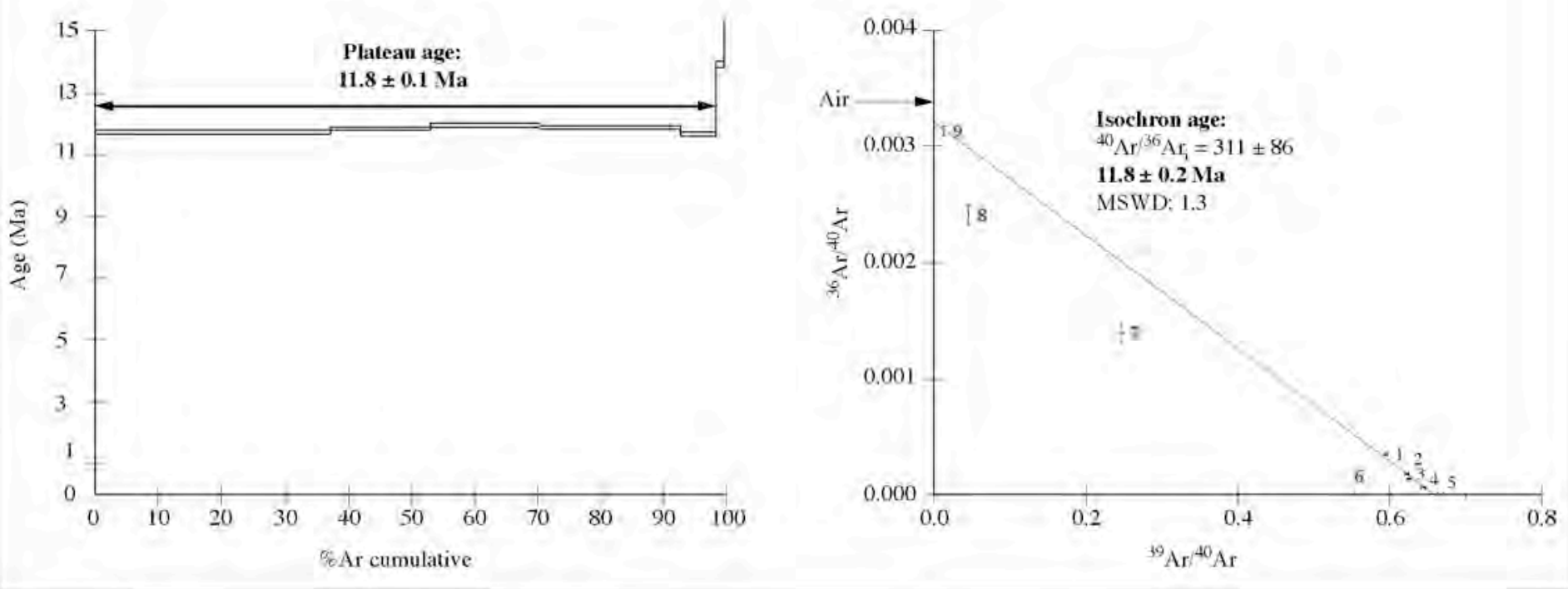

Figure 9 

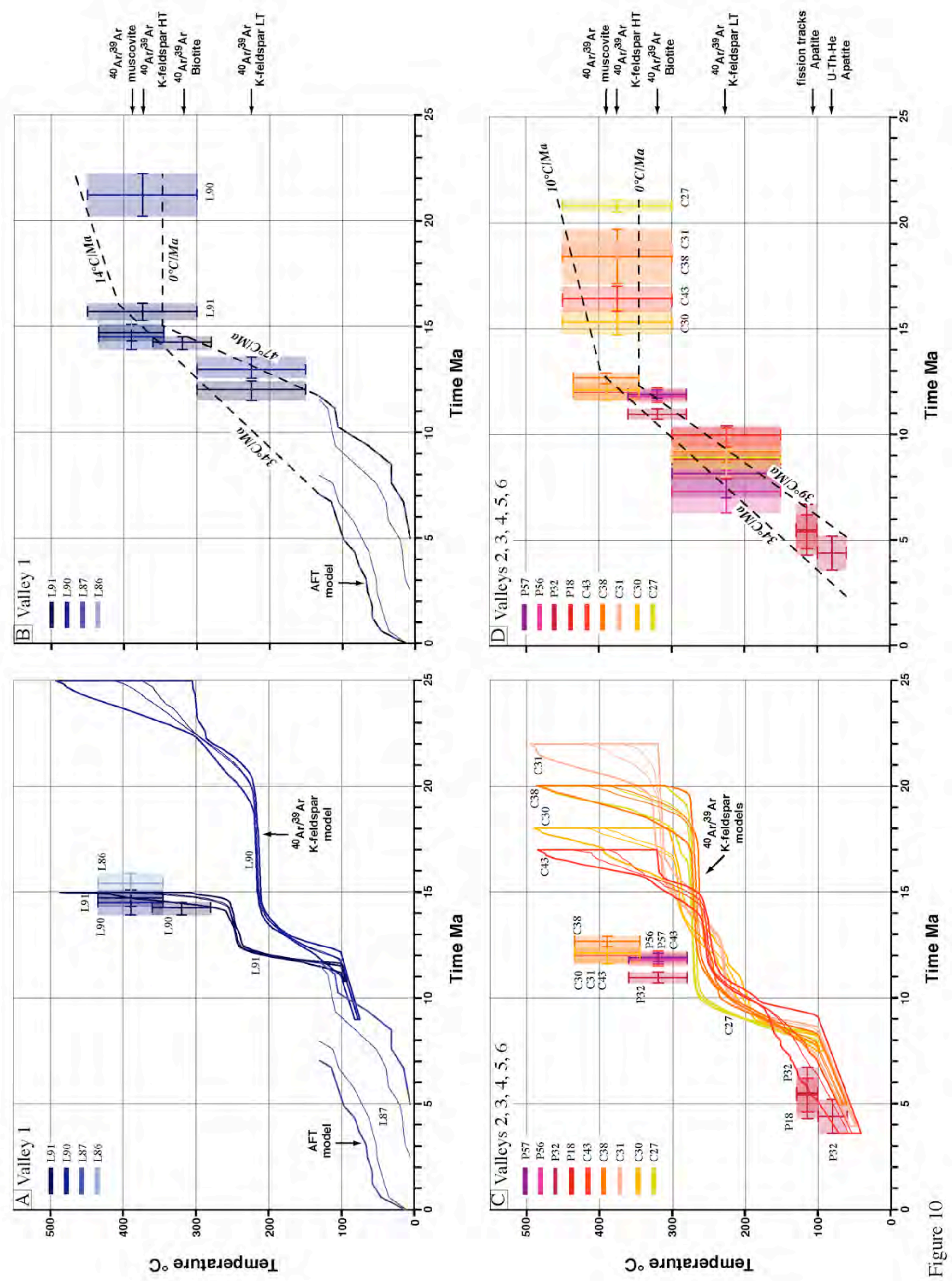

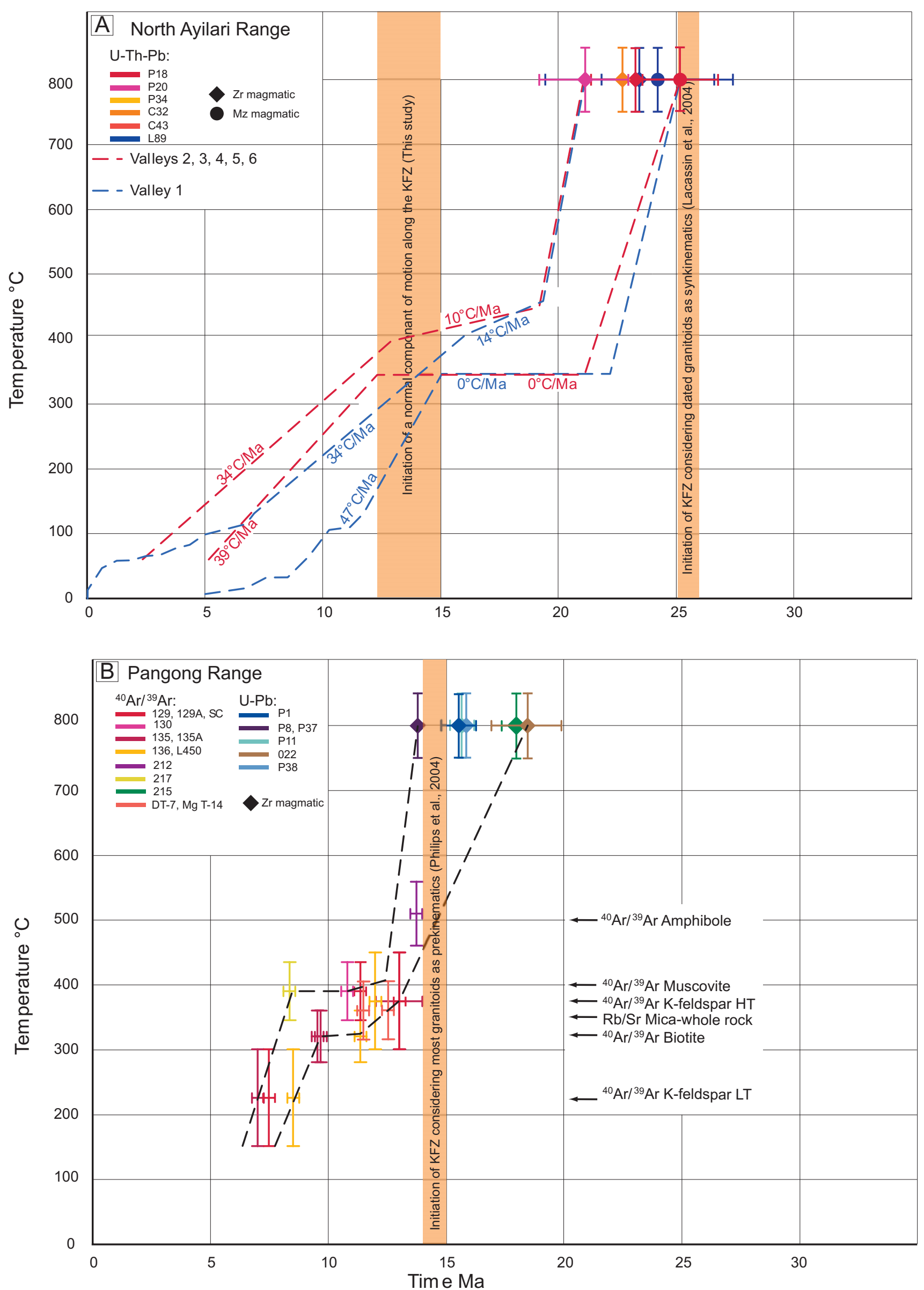

Figure 11 

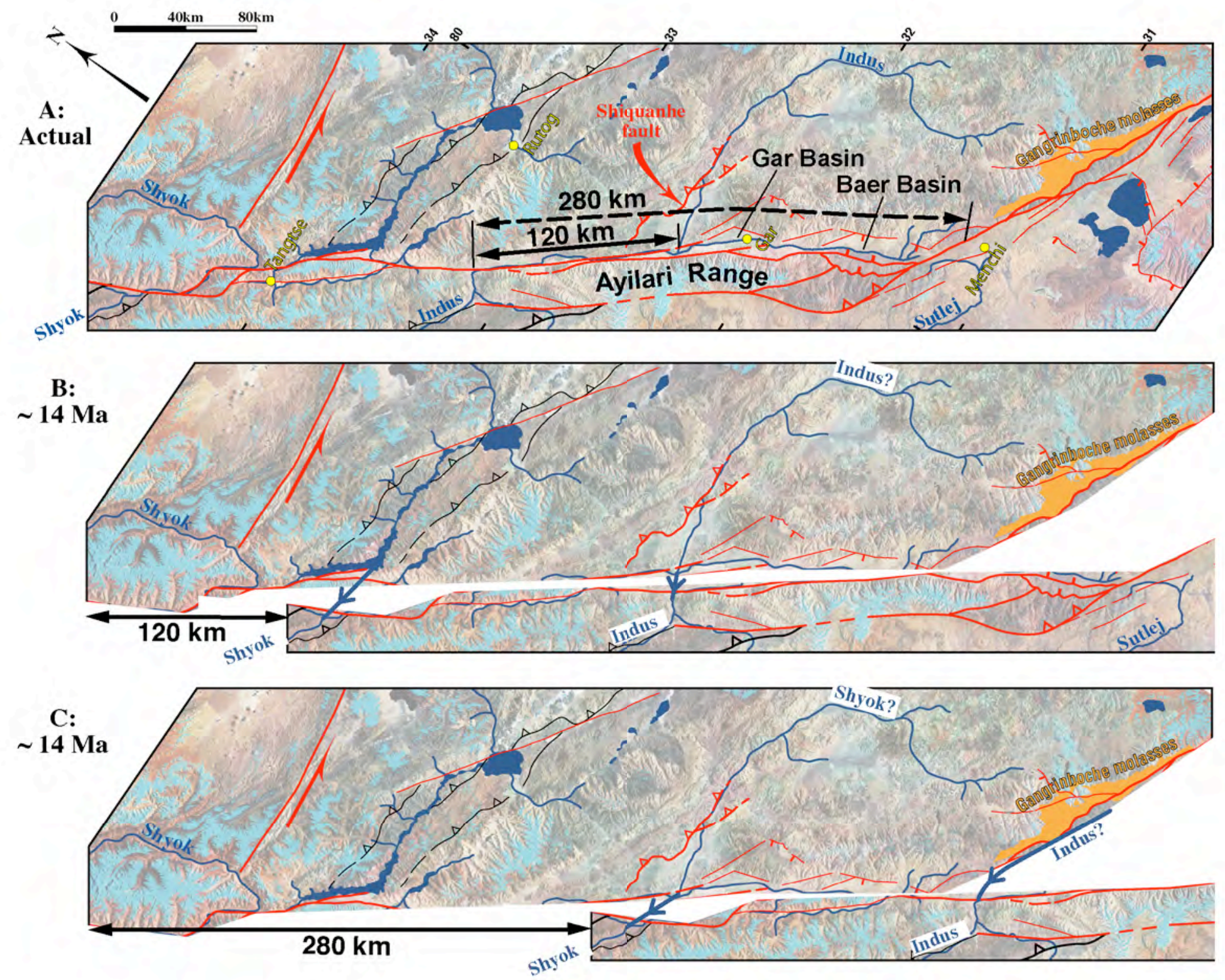

Figure 12 
Table 1

\begin{tabular}{|c|c|c|c|c|c|c|c|c|c|c|c|c|}
\hline Minerals & Quartz & Feldspar & Muscovite & Biotite & Chl & Grt & $\begin{array}{l}\text { Tita } \\
\text { nite }\end{array}$ & Ox & Ep & Ap & $\begin{array}{l}\text { Minerals } \\
\text { dated }\end{array}$ & $\begin{array}{c}\text { Temperature of } \\
\text { deformation }\left({ }^{\circ} \mathrm{C}\right)\end{array}$ \\
\hline $\mathrm{C} 27$ & $25 \%,<0,4$ & $35 \%,<1,5$ & $10 \%,<0,01$ & - & $10 \%$ & - & - & $10 \%$ & $10 \%$ & - & Kfs & From $>600-400$ to $<250$ \\
\hline $\mathrm{C} 30$ & $40 \%,<0,5$ & $35 \%,<5$ & $20 \%,<5$ & - & $1 \%$ & $5 \%,<1$ & - & $<1 \%$ & $<1 \%$ & - & Kfs, Ms & From $>600-400$ to $<250$ \\
\hline C31 & $50 \%,<0,5$ & $40 \%,<1,5$ & $10 \%,<2$ & $<1 \%$ & $<1 \%$ & - & - & - & - & - & $\mathrm{Kfs}, \mathrm{Ms}$ & From $>600-400$ to $<250$ \\
\hline C38 & $50 \%,<0,5$ & $35 \%,<2$ & $15 \%,<1$ & - & $<1 \%$ & - & - & - & - & - & Kfs, Ms & From $>600-400$ to $<250$ \\
\hline $\mathrm{C} 43$ & $30 \%, 0.1-1$ & $\begin{array}{c}55 \%, 0.1- \\
15\end{array}$ & $10 \%,<5$ & $3 \%,<5$ & $2 \%$ & - & - & $<1 \%$ & - & - & $\mathrm{Kfs}, \mathrm{Ms}, \mathrm{Bt}$ & From $>600-400$ to $<250$ \\
\hline L86 & $35 \%, \sim 1$ & $40 \%, 1-5$ & $20 \%, \sim 1$ & $5 \%, \sim 1$ & $<1 \%$ & - & - & $<1 \%$ & - & - & Ms & no deformation \\
\hline L87 & $30 \%,<0.5$ & $\begin{array}{c}45 \%, 0.5- \\
10\end{array}$ & $10 \%, \sim 0.5$ & $15 \%, \sim 0.5$ & $<1 \%$ & - & - & $<1 \%$ & - & $<1 \%$ & Ap & no deformation \\
\hline L90 & $40 \%, \sim 1$ & $35 \%, 1-5$ & $15 \%, \sim 1$ & $5 \%, \sim 1$ & $<1 \%$ & - & - & $<1 \%$ & - & - & Kfs, Ms & From $>600-400$ to $<250$ \\
\hline L91 & $40 \%,<0,5$ & $50 \%,<1,5$ & $8 \%,<1$ & $1 \%$ & $1 \%$ & - & - & $<1 \%$ & - & - & $\mathrm{Kfs}, \mathrm{Ms}, \mathrm{Bt}$ & From $>600-400$ to $<250$ \\
\hline P18 & $20 \%,<0.1$ & $40 \%,<10$ & $20 \%,<1$ & $15 \%,<1$ & - & - & - & $<1 \%$ & - & $<1 \%$ & Ap & From $>600-400$ to $<250$ \\
\hline P32 & $30 \%,<0,5$ & $50 \%,<10$ & $10 \%,<0,01$ & $5 \%$ & $10 \%$ & - & $1 \%$ & $3 \%$ & $1 \%$ & $<1 \%$ & $\mathrm{Kfs}, \mathrm{Bt}, \mathrm{Ap}$ & From $>600-400$ to $<250$ \\
\hline P56 & $30 \%,<1$ & $45 \%,<3$ & $5 \%,<0,01$ & $15 \%$ & $5 \%$ & - & - & $<1 \%$ & - & - & $\mathrm{Bt}$ & no deformation \\
\hline P57 & $30 \%,<1$ & $45 \%,<3$ & $5 \%,<0,01$ & $15 \%$ & $5 \%$ & - & - & $<1 \%$ & - & - & $\mathrm{Kfs}, \mathrm{Bt}$ & no deformation \\
\hline
\end{tabular}


Table 2

mass mean r. mean 1. $\mathrm{U} \quad \mathrm{Th}$ Raw age $\begin{gathered}\mathrm{He} \\ (\mathrm{nmol} / \mathrm{g}\end{gathered} \mathrm{Ft}$ Corrected Incert.

\begin{tabular}{ccccccccccc} 
& $(\mu \mathrm{g})$ & $(\mu \mathrm{m})$ & $(\mu \mathrm{m})$ & $(\mathrm{ppm})$ & $(\mathrm{ppm})$ & $(\mathrm{Ma})$ & $(\mathrm{nmol} / \mathrm{g}$ & $\mathrm{Ft}$ & Age $(\mathrm{Ma})$ & $(1 \sigma)$ \\
\hline $\mathrm{K} 3 \mathrm{P} 32 \mathrm{~A}$ & 41.1 & 81.4 & 282.8 & 10 & 24.04 & 3.1 & 0.26 & 0.82 & 3.7 & $0.1 *$
\end{tabular}

$\begin{array}{lllllllllll}\text { K3P32B } & 34.6 & 69.3 & 336.4 & 12.91 & 32.48 & 3.7 & 0.42 & 0.8 & 4.7 & 0.1 \text { * }\end{array}$

\begin{tabular}{ccccccccccc} 
K3P32C & 17.2 & 56.4 & 250.7 & 14.43 & 35.49 & 3.6 & 0.45 & 0.75 & 4.8 & $0.2 *$ \\
\hline Mean & & & & & & & & & $\mathbf{4 . 4}$ & $\mathbf{0 . 4}$
\end{tabular}




\begin{tabular}{|c|c|c|c|c|c|c|c|c|c|}
\hline \multirow{2}{*}{ Section/site } & \multicolumn{2}{|c|}{$\begin{array}{l}\text { Sample } \\
\end{array}$} & \multicolumn{3}{|c|}{ Plateau Age } & \multicolumn{4}{|c|}{ Inverse Isochron Age } \\
\hline & Number & Location & & Age. Ma & Steps & Age. Ma & $40 \mathrm{Ar} / 36 \mathrm{Ari}$ & MSWD & Steps \\
\hline $\begin{array}{l}\text { Section } 1 . \\
\text { frontal part }\end{array}$ & L90 & $\begin{array}{l}32^{\circ} 23^{\prime} 45.8^{\prime \prime} \mathrm{N} \\
79^{\circ} 33^{\prime} 30.0^{\prime \prime} \mathrm{E}\end{array}$ & Plateau & LT: $13.2 \pm 0.4$ & $\begin{array}{l}4 \text { steps } / 26(2- \\
5) 10 \% \text { of gas }\end{array}$ & $12.7 \pm 0.2$ & $568 \pm 25$ & 0.6 & $\begin{array}{c}14 \text { steps } / 26(2-15) \\
31 \% \text { of gas }\end{array}$ \\
\hline \multirow{3}{*}{$\begin{array}{l}\text { Section } 1 . \\
\text { frontal part }\end{array}$} & & & SMA & HT: $21.2 \pm 1.0$ & $\begin{array}{c}13 \text { steps } / 26 \\
(13-26) 68 \% \\
\text { of gas } \\
\end{array}$ & - & - & - & - \\
\hline & L91 & $\begin{array}{l}32^{\circ} 28^{\prime} 46.9^{\prime \prime} \mathrm{N} \\
79^{\circ} 36^{\prime} 45.0^{\prime \prime} \mathrm{E}\end{array}$ & Plateau & LT: $12.1 \pm 0.3$ & $\begin{array}{l}8 \text { steps } / 26(2- \\
9) 19 \% \text { of gas }\end{array}$ & $11.9 \pm 0.4$ & $719 \pm 120$ & 0.6 & $\begin{array}{c}14 \text { steps } / 26(2-15) \\
34 \% \text { of gas }\end{array}$ \\
\hline & & & SMA & HT: $15.7 \pm 0.4$ & $\begin{array}{c}\text { 4steps } / 26(21- \\
25) 36 \% \text { of } \\
\text { gas } \\
\end{array}$ & - & - & - & - \\
\hline \multirow[t]{2}{*}{$\begin{array}{l}\text { Section } 2 . \\
\text { frontal part }\end{array}$} & $\mathrm{C} 38$ & $\begin{array}{l}32^{\circ} 25^{\prime} 01.1 " \mathrm{~N} \\
79^{\circ} 42^{\prime} 09.4^{\prime \prime} \mathrm{E}\end{array}$ & Plateau & LT: $9.3 \pm 0.3$ & $\begin{array}{l}4 \text { steps } / 25(2- \\
5) 9 \% \text { of gas }\end{array}$ & $9.1 \pm 0.4$ & $540 \pm 80$ & 4.1 & $\begin{array}{c}12 \text { steps } / 25(2-13) \\
21 \% \text { of gas }\end{array}$ \\
\hline & & & SMA & HT: $18.4 \pm 1.3$ & $\begin{array}{c}4 \text { steps } / 25(22- \\
25) 44 \% \text { of } \\
\text { gas } \\
\end{array}$ & $17.0 \pm 1.0$ & $420 \pm 90$ & 5.1 & $\begin{array}{c}4 \text { steps } / 25(22-25) \\
44 \% \text { of gas }\end{array}$ \\
\hline \multirow[t]{2}{*}{$\begin{array}{l}\text { Section } 3 . \\
\text { frontal part }\end{array}$} & $\mathrm{C} 27$ & $\begin{array}{c}32^{\circ} 23^{\prime} 28.9^{\prime \prime} \mathrm{N} \\
79^{\circ} 43^{\prime} 35 . " \mathrm{E}\end{array}$ & Plateau & LT: $9.0 \pm 0.3$ & $\begin{array}{l}4 \text { steps } / 26(2- \\
\text { 5) } 10 \% \text { of gas }\end{array}$ & $8.8 \pm 0.4$ & $533 \pm 34$ & 3.5 & $\begin{array}{c}13 \text { steps } / 26(2-14) \\
24 \% \text { of gas }\end{array}$ \\
\hline & & & $\begin{array}{c}\text { HT at highest } \\
\text { step }\end{array}$ & $20.8 \pm 0.3$ & - & - & - & - & - \\
\hline $\begin{array}{l}\text { Section } 3 . \\
\text { frontal part }\end{array}$ & $\mathrm{C} 30$ & $\begin{array}{l}32^{\circ} 23^{\prime} 28.9^{\prime \prime} \mathrm{N} \\
79^{\circ} 43^{\prime} 35.0^{\prime \prime} \mathrm{E}\end{array}$ & Plateau & LT: $9.0 \pm 0.3$ & $\begin{array}{l}4 \text { steps } / 26(2- \\
\text { 5) } 7 \% \text { of gas }\end{array}$ & $8.7 \pm 0.3$ & $600 \pm 54$ & 1.9 & $\begin{array}{c}12 \text { steps } / 26(2-13) \\
18 \% \text { of gas }\end{array}$ \\
\hline \multirow{3}{*}{$\begin{array}{l}\text { Section 3. } \\
500 \mathrm{~m} \text { from } \\
\text { front }\end{array}$} & & & Plateau & HT: $15.3 \pm 0.6$ & $\begin{array}{c}3 \text { steps } / 26(23- \\
25) 44 \% \text { of } \\
\text { gas } \\
\end{array}$ & - & - & - & - \\
\hline & $\mathrm{C} 31$ & $\begin{array}{l}32^{\circ} 23^{\prime} 17.6^{\prime \prime} \mathrm{N} \\
79^{\circ} 43^{\prime} 25.3^{\prime \prime} \mathrm{E}\end{array}$ & Plateau & LT: $9.7 \pm 0.2$ & $\begin{array}{l}6 \text { steps } / 26(2- \\
7) 15 \% \text { of gas }\end{array}$ & $8.8 \pm 0.8$ & $807 \pm 200$ & 10 & $\begin{array}{c}14 \text { steps } / 26(2-15) \\
30 \% \text { of gas }\end{array}$ \\
\hline & & & SMA & HT: $18.7 \pm 0.4$ & $\begin{array}{c}3 \text { steps } / 26(23- \\
25) 37 \% \text { of } \\
\text { gas } \\
\end{array}$ & - & - & - & - \\
\hline \multirow[t]{2}{*}{$\begin{array}{l}\text { Section } 4 . \sim \\
3.5 \mathrm{~km} \text { from } \\
\quad \text { front }\end{array}$} & $\mathrm{C} 43$ & $\begin{array}{l}32^{\circ} 19^{\prime} 22.7^{\prime \prime} \mathrm{N} \\
79^{\circ} 44 ' 25.3^{\prime \prime} \mathrm{E}\end{array}$ & Plateau & LT: $10.1 \pm 0.2$ & $\begin{array}{l}4 \text { steps } / 26(2- \\
5) 11 \% \text { of gas }\end{array}$ & $9.8 \pm 0.4$ & $606 \pm 44$ & 2.1 & $\begin{array}{c}14 \text { steps } / 26(2-15) \\
29 \% \text { of gas }\end{array}$ \\
\hline & & & Plateau & HT: $16.3 \pm 0.6$ & $\begin{array}{c}3 \text { steps } / 26(24- \\
\text { 26) } 35 \% \text { of } \\
\text { gas } \\
\end{array}$ & - & - & - & - \\
\hline Outcrop 5 & P56 & $\begin{array}{l}32^{\circ} 08^{\prime} 14.7 " \mathrm{~N} \\
79^{\circ} 56^{\prime} 12.9^{\prime \prime} \mathrm{E}\end{array}$ & SMA & LT: $7.3 \pm 1.0$ & $\begin{array}{c}11 \text { steps } / 27(4- \\
\text { 14) } 18 \% \text { of } \\
\text { gas }\end{array}$ & - & - & - & - \\
\hline \multirow{3}{*}{ Outcrop 5} & & & SMA & HT: $\geq 16$ & - & - & - & - & - \\
\hline & P57 & $\begin{array}{l}32^{\circ} 08^{\prime} 14.7^{\prime \prime} \mathrm{N} \\
79^{\circ} 56^{\prime} 12.9^{\prime \prime} \mathrm{E}\end{array}$ & SMA & LT: $8.3 \pm 1.0$ & $\begin{array}{l}6 \text { steps } / 31 \text { (3- } \\
\text { 8) } 9 \% \text { of gas }\end{array}$ & $8.0 \pm 1.0$ & $358 \pm 60$ & 30 & $\begin{array}{c}18 \text { steps } / 31(2-19) \\
35 \% \text { of gas }\end{array}$ \\
\hline & & & SMA & HT: $\geq 16$ & - & - & - & - & - \\
\hline $\begin{array}{l}\text { Section } 6 . \\
\text { frontal part }\end{array}$ & P32 & $\begin{array}{l}32^{\circ} 01^{\prime} 38.4^{\prime \prime} \mathrm{N} \\
80^{\circ} 00^{\prime} 38.2^{\prime \prime} \mathrm{E}\end{array}$ & Plateau & LT: $9.0 \pm 1.4$ & $\begin{array}{l}4 \text { steps } / 30(2- \\
\text { 5) } 6 \% \text { of gas }\end{array}$ & $8.7 \pm 0.8$ & $295 \pm 29$ & 2.8 & $\begin{array}{c}4 \text { steps } / 30(2-5) 6 \% \\
\text { of gas }\end{array}$ \\
\hline
\end{tabular}




\begin{tabular}{|c|c|c|c|c|c|c|c|c|c|c|}
\hline \multirow{2}{*}{ Section/site } & \multicolumn{2}{|c|}{ Sample } & \multicolumn{3}{|c|}{ Plateau Age } & \multicolumn{4}{|c|}{ Inverse Isochron Age } & \multirow[t]{2}{*}{$\begin{array}{c}\text { Total Fusion } \\
\text { Age } \\
\end{array}$} \\
\hline & Number & Location & & Age, $\mathrm{Ma}$ & Steps & Age, $\mathrm{Ma}$ & 40Ar/36Ari & MSWD & Steps & \\
\hline $\begin{array}{l}\text { Section } 1 . \\
\text { frontal part }\end{array}$ & L91 & $\begin{array}{l}32^{\circ} 28^{\prime} 46.9^{\prime \prime} \mathrm{N} \\
79^{\circ} 36^{\prime} 45.0^{\prime \prime} \mathrm{E}\end{array}$ & Plateau & $14.7 \pm 0.1$ & $\begin{array}{c}4 \text { steps } / 8(1-4) \\
85 \% \text { of gas }\end{array}$ & $14.7 \pm 0.4$ & $305 \pm 14$ & 5.3 & $\begin{array}{c}8 \text { steps } / 8(1-8) \\
100 \% \text { of gas }\end{array}$ & $14.8 \pm 0.2$ \\
\hline $\begin{array}{l}\text { Section } 1 . \\
\text { frontal part }\end{array}$ & L90 & $\begin{array}{l}32^{\circ} 23^{\prime} 45.8^{\prime \prime} \mathrm{N} \\
79^{\circ} 33^{\prime} 30.0^{\prime \prime} \mathrm{E} \\
\end{array}$ & SMA & $14.5 \pm 0.6$ & $\begin{array}{c}7 \text { steps } / 9(1-7) \\
98 \% \text { of gas } \\
\end{array}$ & $14.5 \pm 0.4$ & $308 \pm 40$ & 1.6 & $\begin{array}{c}6 \text { steps } / 8(1-6) \\
98 \% \text { of gas } \\
\end{array}$ & $14.7 \pm 0.2$ \\
\hline $\begin{array}{l}\text { Section } 1 . \sim 10 \\
\mathrm{~km} \text { from front }\end{array}$ & L86 & $\begin{array}{l}32^{\circ} 23^{\prime} 45.8^{\prime \prime} \mathrm{N} \\
79^{\circ} 33^{\prime} 30.0^{\prime \prime} \mathrm{E}\end{array}$ & Plateau & $15.4 \pm 0.5$ & $\begin{array}{c}5 \text { steps/7 (1-5) } \\
98 \% \text { of gas }\end{array}$ & $15.4 \pm 0.4$ & $325 \pm 34$ & 2.7 & $\begin{array}{c}7 \text { steps } / 7 \\
100 \% \text { of gas }\end{array}$ & $15.4 \pm 0.2$ \\
\hline $\begin{array}{l}\text { Section } 2 . \\
\text { frontal part }\end{array}$ & C 38 & $\begin{array}{l}32^{\circ} 25^{\prime} 01.1^{\prime \prime} \mathrm{N} \\
79^{\circ} 42^{\prime} 09.4^{\prime \prime} \mathrm{E}\end{array}$ & SMA & $12.6 \pm 0.2$ & $\begin{array}{c}6 \text { steps } / 9(1-6) \\
98 \% \text { of gas }\end{array}$ & $12.7 \pm 0.2$ & $297 \pm 4$ & 1.0 & $\begin{array}{c}8 \text { steps } / 8 \\
100 \% \text { of gas }\end{array}$ & $12.6 \pm 0.1$ \\
\hline $\begin{array}{l}\text { Section } 3 . \\
\text { frontal part }\end{array}$ & $\mathrm{C} 30$ & $\begin{array}{l}32^{\circ} 23^{\prime} 28.9^{\prime \prime} \mathrm{N} \\
79^{\circ} 43^{\prime} 35.0^{\prime \prime} \mathrm{E} \\
\end{array}$ & Plateau & $12.0 \pm 0.4$ & $\begin{array}{c}5 \text { steps } / 8(2-6) \\
93 \% \text { of gas } \\
\end{array}$ & $12.2 \pm 0.2$ & $241 \pm 24$ & 0.3 & $\begin{array}{c}6 \text { steps } / 8(1-6) \\
93 \% \text { of gas } \\
\end{array}$ & $11.9 \pm 0.1$ \\
\hline $\begin{array}{l}\text { Section 3. } \\
500 \mathrm{~m} \text { from } \\
\text { front }\end{array}$ & $\mathrm{C} 31$ & $\begin{array}{l}32^{\circ} 23^{\prime} 17.6^{\prime \prime} \mathrm{N} \\
79^{\circ} 43^{\prime} 25.3^{\prime \prime} \mathrm{E}\end{array}$ & Plateau & $12.1 \pm 0.2$ & $\begin{array}{c}4 \text { steps/7 (2-5) } \\
86 \% \text { of gas }\end{array}$ & $12.0 \pm 0.4$ & $332 \pm 44$ & 3 & $\begin{array}{c}5 \text { steps/7 (1-5) } \\
92 \% \text { of gas }\end{array}$ & $12.4 \pm 0.3$ \\
\hline $\begin{array}{l}\text { Section } 4 . \sim \\
3.5 \mathrm{~km} \text { from } \\
\text { front }\end{array}$ & $\mathrm{C} 43$ & $\begin{array}{l}32^{\circ} 19^{\prime} 22.7^{\prime \prime} \mathrm{N} \\
79^{\circ} 44^{\prime} 25.3^{\prime \prime} \mathrm{E}\end{array}$ & Plateau & $12.0 \pm 0.4$ & $\begin{array}{c}4 \text { steps } / 6(1-4) \\
97 \% \text { of gas }\end{array}$ & $12.0 \pm 0.4$ & $304 \pm 22$ & 0.8 & $\begin{array}{c}4 \text { steps/6 (1-4) } \\
97 \% \text { of gas }\end{array}$ & $12.0 \pm 0.2$ \\
\hline
\end{tabular}




\begin{tabular}{|c|c|c|c|c|c|c|c|c|c|c|}
\hline \multirow{2}{*}{ Section/site } & \multicolumn{2}{|c|}{ Sample } & \multicolumn{3}{|c|}{ Plateau Age } & \multicolumn{4}{|c|}{ Inverse Isochron Age } & \multirow[t]{2}{*}{$\begin{array}{c}\text { Total Fusion } \\
\text { Age } \\
\end{array}$} \\
\hline & Number & Location & & Age, Ma & Steps & Age, $\mathrm{Ma}$ & 40Ar/36Ari & MSWD & Steps & \\
\hline $\begin{array}{c}\text { Section } 1 . \\
\text { frontal part }\end{array}$ & L91 & $\begin{array}{l}32^{\circ} 28^{\prime} 46.9^{\prime \prime} \mathrm{N} \\
79^{\circ} 36^{\prime} 45.0^{\prime \prime} \mathrm{E}\end{array}$ & Plateau & $14.2 \pm 0.3$ & $\begin{array}{c}4 \text { steps/ } 7(1-4) \\
98 \% \text { of gas }\end{array}$ & $14.3 \pm 0.2$ & $299 \pm 28$ & 1.1 & $\begin{array}{c}5 \text { steps/ } 6(1-5) \\
98 \% \text { of gas } \\
\end{array}$ & $14.2 \pm 0.4$ \\
\hline $\begin{array}{l}\text { Section 4. } \\
3.5 \mathrm{~km} \text { from } \\
\text { front }\end{array}$ & $\mathrm{C} 43$ & $\begin{array}{l}32^{\circ} 19^{\prime} 22.7^{\prime \prime} \mathrm{N} \\
79^{\circ} 44^{\prime} 25.3^{\prime \prime} \mathrm{E}\end{array}$ & Plateau & $11.6 \pm 0.1$ & $\begin{array}{c}6 \text { steps } / 9(1-6) \\
98 \% \text { of gas }\end{array}$ & $12 \pm 0.2$ & $250 \pm 28$ & 0.9 & $\begin{array}{l}6 \text { steps/9 (1- } \\
6) 99 \% \text { of gas }\end{array}$ & $11.6 \pm 0.2$ \\
\hline Outcrop 5 & P56 & $\begin{array}{l}32^{\circ} 08^{\prime} 14.7^{\prime \prime} \mathrm{N} \\
79^{\circ} 56^{\prime} 12.9^{\prime \prime} \mathrm{E}\end{array}$ & Plateau & $11.8 \pm 0.1$ & $\begin{array}{c}7 \text { steps/9 (1-7) } \\
98 \% \text { of gas }\end{array}$ & $11.8 \pm 0.2$ & $311 \pm 86$ & 1.3 & $\begin{array}{c}5 \text { steps/9 (1-5) } \\
98 \% \text { of gas }\end{array}$ & $11.9 \pm 0.2$ \\
\hline Outcrop 5 & P57 & $\begin{array}{l}32^{\circ} 08^{\prime} 14.7^{\prime \prime} \mathrm{N} \\
79^{\circ} 56^{\prime} 12.9^{\prime \prime} \mathrm{E}\end{array}$ & Plateau & $11.9 \pm 0.1$ & $\begin{array}{l}7 \text { steps/10 (1- } \\
7) 94 \% \text { of gas } \\
\end{array}$ & $11.9 \pm 0.2$ & $316 \pm 60$ & 3.3 & $\begin{array}{l}7 \text { steps/10 (1- } \\
7) 94 \% \text { of gas } \\
\end{array}$ & $12.2 \pm 0.2$ \\
\hline $\begin{array}{c}\text { Section } 6 . \\
\text { frontal part }\end{array}$ & P32 & $\begin{array}{l}32^{\circ} 01^{\prime} 38.4^{\prime \prime} \mathrm{N} \\
80^{\circ} 00^{\prime} 38.2^{\prime \prime} \mathrm{E} \\
\end{array}$ & Plateau & $10.9 \pm 0.2$ & $\begin{array}{l}3 \text { steps } / 10(2- \\
4) 40 \% \text { of gas }\end{array}$ & $11.0 \pm 0.2$ & $311 \pm 8$ & 0.7 & $\begin{array}{l}4 \text { steps } / 10(1- \\
\text { 4) } 99 \% \text { of gas }\end{array}$ & $11.1 \pm 0.1$ \\
\hline
\end{tabular}


Table 6

\begin{tabular}{|c|c|c|c|c|c|c|c|c|c|c|c|c|c|c|c|}
\hline \multirow[b]{2}{*}{$\begin{array}{l}\text { Sample } \\
\text { number }\end{array}$} & \multirow[b]{2}{*}{$\begin{array}{c}\text { Elevation } \\
\text { (m) }\end{array}$} & \multirow[b]{2}{*}{ Location } & \multicolumn{2}{|c|}{ Spontaneous } & \multicolumn{2}{|c|}{ Induced } & \multicolumn{2}{|c|}{ Dosimeter } & \multicolumn{3}{|c|}{ Pooled } & \multirow[b]{2}{*}{ length } & \multirow[b]{2}{*}{ $\pm 2 \sigma$} & \multirow[b]{2}{*}{$\mathrm{SD}$} & \multirow[b]{2}{*}{$\mathrm{n}$} \\
\hline & & & $\begin{array}{l}\text { Rho-S } \\
\left(\times 10^{4}\right)\end{array}$ & $\overline{\mathrm{NS}}$ & $\begin{array}{l}\text { Rho-I } \\
\left(\times 10^{6}\right) \\
\end{array}$ & $\mathrm{NI}$ & $\begin{array}{l}\text { Rho-D } \\
\left(\times 10^{6}\right)\end{array}$ & \#ND & $\begin{array}{c}\mathrm{P}(\mathrm{chi})^{2} \\
(\%)\end{array}$ & $\begin{array}{l}\text { Age } \\
(\mathrm{Ma})\end{array}$ & $\begin{array}{r} \pm 1 \mathrm{~s} \mathrm{U} \\
\quad \mathrm{ppm}\end{array}$ & & & & \\
\hline P32 & 4700 & $32^{\circ} 01^{\prime} 38.4^{\prime \prime} \mathrm{N} 80^{\circ} 00^{\prime} 38.2^{\prime \prime} \mathrm{E}$ & 0.0507 & 82 & 2.274 & 3680 & 1.3272 & 5291 & 100 & 5.5 & $0.6 \quad 21$ & & & & 0 \\
\hline P18 & 4500 & $32^{\circ} 23^{\prime} 28.9^{\prime \prime} \mathrm{N} 79^{\circ} 43^{\prime} 35.0^{\prime \prime} \mathrm{E}$ & 0.1023 & 228 & 4.548 & 10137 & 1.3038 & 5291 & 54 & 5.4 & $0.4 \quad 44$ & 13.05 & 2.00 & 2.65 & 7 \\
\hline
\end{tabular}

